\title{
SUVOROV (1940). DE PUDOVKIN: O CINEMA SOVIÉTICO E O CONSERVADORISMO NO EXÉRCITO VERMELHO
}

MOISÉS WAGNER FRANCISCON*

SECRETARIA DE ESTADO DA EDUCACÃO E DO ESPORTE DO PARANÁ - CAMPO MOURÃO PARANÁ

Ao contrário do que aponta a maior parte da historiografia, a reorganização do Exército Vermelho não se deu durante a Batalha de Stalingrado. Tampouco foi obra desenraizada, concebida e imposta rapidamente por um tirano. Ela se inscreve num processo mais lento, iniciado com a década de 1930. O governo soviético lançou uma campanha pelas reformas ainda em 1940, inclusive com o uso do cinema. Apesar da pressão financeira, legal e física sobre os cineastas, RESUMO jamais conseguiu exercer um controle absoluto. O cinema, como aponta Marc Ferro, abre uma janela para uma visão minuciosa de uma sociedade, que poderia passar despercebida sem o uso dessa fonte. $\mathrm{O}$ filme Suvorov (1940), dirigido pelo cineasta soviético Vsevolod Pudovkin, permite realizar uma análise segundo a perspectiva mencionada acima.

Palavras-chave: Pudovkin; Suvorov; Realismo socialista; Sóciohistória cinematográfica.

ABSTRACT

Contrary to what points most of the historiography, the reorganization of the Red Army did not happen during the Battle of Stalingrad. Nor was uprooted piece, conceived and quickly imposed by a tyrant. She is part of a slower process, which began with the 1930's. The Soviet government launched a campaign for reform yet in 1940, including the use of cinema. Despite the financial pressure, legal and physical on the filmmakers, was never able to exercise absolute control. Cinema, as pointed out by Marc Ferro, opens a window to a detailed vision of a society that could go unnoticed without the use of this source. The film Suvorov (1940), directed by Soviet filmmaker Vsevolod Pudovkin, allows for an analysis from the perspective mentioned above.

Keywords: Pudovkin; Suvorov; Socialist realism; Social History of Cinema.

* Doutor em História (UFPR). Professor da Secretaria de Estado da Educação e do Esporte do Paraná, Núcleo Regional de Campo Mourão. Email: mw.franciscon@hotmail.com. 


\section{INTRODUCÃO}

Reformado entre meados e o fim de 1942, o Exército Vermelho abandona a série de batalhas majoritariamente perdidas para assumir a imagem de "rolo compressor" em direção à Berlim. Boa parte da historiografia, em especial a de divulgação, peca ao simplificar esse processo, moldurando-o segundo uma linha de desenvolvimento linear imposto pelas sucessivas derrotas frente ao Eixo. Ao contrário, as reformas foram inconstantes, além de terem sido iniciadas antes do alastramento da Segunda Guerra Mundial ao solo soviético. Foi levada a cabo uma campanha para elevar o nível moral do Exército, com os discursos otimistas de autoridades e também com a sua valorização histórica pelo cinema. Nesse quadro foi rodada a película Suvorov, de 1940, sobre os anos finais (1794-1799) do marechal e generalíssimo russo Alexander Suvorov (1730-1800), conhecido por nunca ter perdido uma batalha. Rodado pelo diretor Vsevolod Pudovkin, a obra estava longe de se constituir como propaganda ideológica do regime - como era do interesse do Kremlin que, no entanto, o financiou em decorrência das expectativas diante desta campanha e como mais um elemento dela. Já para Pudovkin, a maior preocupação era a arte fílmica.

Eisenstein (1898-1948), Vertov (1895-1954), Dovzhenko (1894-1956), Kuleshov (1899-1970), Ermler (1898-1967), Kozintsev (1905-1973), formam a geração de cineastas soviéticos a qual pertence Pudovkin (1893-1953). Seus principais filmes foram rodados nos anos 1920, sob o clima mais livre oferecido pela NEP. ${ }^{1}$ A mãe (Mat, 1926), O fim de São Petersburgo (Konets Sankt-Peterburga, 1927) e Tempestade sobre a Ásia (Potomok ChingisKhana, 1928) inseriram o jovem diretor na galeria dos grandes cineastas inovadores, que fundiam engajamento político com uma estética, montagem e linguagem revolucionárias. $\mathrm{Na}$ mesma época, o próprio ministro escolhido por Lenin para o cinema e a educação, Lunatcharski, produzia comédias e adaptações de romances sem apelo político. Kosntantin Eggert e Vladimir Gardin, em 1926, estrearam sua comédia popular A boda do urso (Medvezhya Svadba), segundo a estética czarista e que arrecadou o dobro de $O$ encouraçado Potemkin. ${ }^{2}$ O que torna voluntário o caminho seguido por Pudovkin. Encomendas estatais que revelavam interesse político em

\footnotetext{
${ }^{1}$ A NEP, Nova Política Econômica, significou uma tentativa de amálgama do socialismo e do estatismo (bancos, comércio externo e indústria continuaram controlados pelo Estado) com capitalismo e mercado em pequenas proporções (agricultura privada, pequenos comerciantes, pequenas manufaturas) (BROWN, 2010, p.59). Como Ferro (1992, p.89) lembra, ocorreu também um abrandamento com a cultura. Filmes supostamente "sem objetivos ideológicos", como Dura Lex (1926), de Kulechov, apareceram. Aelita (1924), de Protazanov, deve integrar qualquer lista com filmes com uma crítica disfarçada ao regime.

${ }^{2}$ LABARRÉRE, A. Z. Atlas del cine. Madrid: AKAL, 2009, p.333
} 
possíveis mensagens já foram feitas ao diretor poucos anos antes. Em 1939 produzira o filme nacionalista Minin i Pozharsky, sobre os dois plebeus que participaram da insurgência moscovita contra o czar fantoche instalado na capital pelos inovadores poloneses em 1612, restituindo o poder à recém-instalada dinastia Romanov. Mais uma vez, personagens que faziam parte do panteão de heróis czaristas (receberam o monumento em frente à catedral de São Basílio em 1818, no clima da expulsão e derrota de Napoleão) são reabilitadas, relidas (eram os cidadãos Minin e Pozharsky) e reconsagradas.

Na mesma década, escreve dois livros sobre cinema, um sobre direção e outro sobre roteiro. Esses elementos o afastam de Eisenstein e de Vertov. O roteiro é concebido de uma maneira ainda mais importante, estrutural para todo o filme, do que em Eisenstein. Vertov quase o dispensa. A mesma distinção ocorre com o uso de atores. Vertov os abole. Condenava o cinema atuado, preferindo as imagens captadas por sua câmera no improviso das ruas. Eisenstein mantinha os atores e suas falas, porém os buscava como tipos ideais, retirados da população e sem experiência profissional no campo. Pudovkin preferia artistas vindos do teatro, mesmo com a constituição de um sistema de estrelato cinematográfico, com a modernização do cinema soviético nos moldes de Hollywood, nos anos 1930. Também prefere personagens individualizados e definidos, sem, no entanto, cair no psicologismo ${ }^{3}$.

Ambicionava integrar o poder decisivo do diretor sem comprometer o roteiro; criar personagens portadores de uma personalidade e de uma mensagem; utilizar a metáfora como base para a trama de seus filmes. A montagem era vista principalmente como possuindo função estética, não conduzindo ou moldando a dramaticidade, como em Eisenstein. O drama para Pudovkin adquire uma importância própria. Mesmo inovador, suas películas carregam um estilo um pouco mais convencional, fluído.

Todavia, com o fortalecimento da estrutura de estúdios, diretores, comitês e agências ministeriais fiscalizadoras, ${ }^{4}$ sua liberdade criativa foi reduzida. Precisou encontrar novas formas de se enquadrar nas orientações e necessidades emanadas pelas autoridades, sob a escola

\footnotetext{
3 "O indivíduo antes que as massas anônimas; rostos reconhecíveis antes que uma galeria de retratos, por deslumbrante que possa resultar: tais são os matizes introduzidas por Pudovkin [...]. São figuras que se impõe pelo que representam, mas também pelo que são [...]. Em seu aparato teórico, o ator unicamente é 'um material bruto para a composição futura de sua imagem no filme, organizada pela montagem'. Com isso, deixa clara sua postura: o filme deve conduzir a uma tomada de consciência, e sua eficácia passa pelo trabalho da forma, que se apoia na montagem e no recurso a um discurso metafórico". A produção teórica de Pudovkin não pararia aí. Em 1928 escreveu, juntamente com Eisenstein e Alexandrov o manifesto O porvir do filme sonoro, um "manifesto do contraponto orquestral", que defende o uso não realista do som (LABARRÉRE, 2009, p.329; 331).

${ }^{4}$ KENEZ, P. Cinema and Soviet society, 1917-1953. Cambridge: Cambridge Press, 1992, p.78-82.
} 
do realismo socialista, ao mesmo tempo que encontrar espaços para exercer seus projetos, de maneira pessoal. O que não era difícil para um teórico da linguagem metafórica e alegórica no cinema. O que não impediu de obter o mesmo reconhecimento dos anos 1920 nas décadas seguintes.

As premissas da escola oficial se distanciavam menos de Pudovkin do que de Eisenstein ou Vertov (praticamente ejetado do ramo no fim da década de 1930). Cobrava dos diretores - apesar de nem sempre o conseguir - personagens individualizados, roteiro mais simples, histórias lineares, para assim atrair a atenção popular, dominada pelas produções americanas exibidas na URSS, além de uma defesa da ideologia socialista, centrada na luta dos trabalhadores, na justiça, etc. Elementos como o herói positivo, o clima otimista, o final feliz, além da própria pressão pela simplificação e redução, para que a ampla massa de camponeses ainda não alfabetizados e com uma gama de experiências e possibilidades de leituras diferentes das do público urbano, ${ }^{5}$ serviam como uma camisa-de-força criativa.

Ferro (1992) demonstrou como Chapayev (1936) - o filme modulador do realismo socialista - apesar de se pretender engajado na ideologia revolucionária de Outubro, acabava criando ressonância para todas as manifestações reacionárias promovidas pelas mudanças enfrentadas pelo país nos anos 1930: o conservadorismo social stalinista, o autoritarismo político, etc. Sua metodologia é conhecida por sócio-história cinematográfica. "A leitura histórica e social do filme [...] permitiu-nos atingir zonas não visíveis do passado das sociedades, revelando, por exemplo, as autocensuras e os lapsos de uma sociedade". ${ }^{6} \mathrm{O}$ filme seria uma fonte única porque não pode ser controlado por força alguma. O poder do dinheiro, no mundo capitalista, ou o político-ideológico, no socialista, ou outras instituições com influência sobre a sociedade, como a religião, seriam incapazes de manipular totalmente as imagens e as mensagens fílmicas. O próprio diretor não o poderia, por mais minuciosa que fosse sua autocensura ou seu engajamento. O cinema sempre mostraria mais do que o pretendido, consciente ou inconscientemente. Outro fator que impossibilita seu controle é a capacidade de provocar múltiplas leituras pela plateia, segundo a época de exibição do filme, o lugar, ou mesmo as diferenciações dentro de um mesmo público, apesar dos esforços dos produtores ${ }^{7}$.

\footnotetext{
${ }^{5}$ LAWTON, A. (Org.). The Red screen. Londres: Routledge, 1992, p.257.

${ }^{6}$ FERRO, M. Cinema e História. São Paulo: Paz e Terra, 1992, p.19.

${ }^{7}$ Mensagens diferentes também se submetem a leituras diferentes: "um fenômeno como esse deve ser analisado não somente através de civilizações diferentes (cidade/campo, Ocidente/Oriente, mundo negro/branco, etc.), em sua diacronia, mas também no seio de uma mesma
} 
Recurso que permite atingir as estruturas de uma sociedade, dificilmente apreensíveis por outros objetos, como documentos escritos, por possuir mais lacunas que este. Até mesmo porque o real não é apenas descrito pictoricamente, mas também encenado como imagem. Ao expor os lapsos e contradições de uma organização social, ou mesmo oferecer a visão de grupos dissidentes e opositores, numa destruição frontal do discurso oficial, o filme abriria as portas para uma contra-análise da sociedade. ${ }^{8}$ Por trás da construção de um filme existe uma zona de realidade não-visível; intricado no conteúdo aparente existe um conteúdo latente, o qual pode revelar algo sobre uma dada realidade. Considera ainda, que a identificação dos lapsos fragmentos involuntários que escapam aos objetivos de quem produz o filme - seria o meio para se chegar a esse elemento real oculto. A proposta de Ferro concebe o sistema soviético, ou qualquer outro, como impossibilitado de se impor de forma totalitária a essa forma de arte, que sempre preserva sua autonomia.

Além de ser uma fonte válida na ausência de material escrito, é também um importante documento para a apreensão do imaginário. Ou, como aponta Oliveira, o mais importante campo do imaginário social no século $\mathrm{XX}^{9}{ }^{9}$ Suvorov trabalha com essa faceta das representações históricas populares ao remodelar a visão do papel das forças armadas do país, estabelecendo uma ponte entre imagens do passado e o presente. Se não abordasse o imaginário popular, não seria capaz de insinuar quaisquer mensagens, como objetivava o regime de Stalin.

cultura. Diga-se o mesmo da maneira como uma figura de escrita ou um estilo permanecem ativos ou se tornam ultrapassados, caem nas graças desse ou daquele público que, ele próprio, também muda. O mesmo se passa com o conteúdo e a significação de uma obra. Esta pode ser lida de maneira diferente e mesmo inversa, em dois momentos diferentes de sua história" (FERRO, 1992, p.18).

${ }^{8}$ FERRO, 1976, p.202-203.

${ }^{9}$ OLIVEIRA, D. O cinema como fonte para a história. Fontes históricas: métodos e tipologias, 2008, Curitiba. III Evento de Extensão em Pesquisa Histórica, 2008. 
Figura.1. Suvorov (Nikolai Cherkasov)



Suvorov (Nikolai Cherkasov) como líder, colocado acima da tropa, e como mais um de seus homens. Fonte: SUVOROV, 1940.

$\mathrm{Na}$ classificação formulada por Ferro, Suvorov estaria localizado entre o filme histórico positivista, preocupado com uma reconstrução exata do passado, e o filme novelesco, que narra uma ficção ambientada historicamente. ${ }^{10}$ As proposições de Rosenstone, de que a fidelidade histórica não é o objetivo do cinema e que a ficção é necessária artisticamente, para tornar a narrativa fluída, estruturada e interessante - o que seria seu real objetivo - são interessantes para alguns casos, mas podem ocultar interesses presentes nessas modificações. ${ }^{11}$ O carisma do protagonista poderia permanecer por meio de sua excentricidade, enquanto poderse-ia suprimir seu fictício caráter popular por um mais adequado tom nobiliárquico. A aproximação com seus homens, não apenas física, na linha de frente, como muitos líderes militares o faziam, mas também em pensamento, comportamento, motivação, alma (e, oportunamente sua real inclinação para vestimentas simples quando longe da corte ou da hierarquia militar), possuía um interesse político sútil, bem como diversas outras passagens, reais ou ficcionais. A criação dessas cenas ou sua inclusão a partir da factualidade histórica não era desmotivada para além do aprimoramento do filme como entretenimento ou arte. A percepção de interesses políticos de classes e grupos ou da mentalidade e do espírito de uma sociedade e uma época tornam Ferro acurado, ao contrário de Rosenstone, que os naturaliza e suprime. Combinam-se num todo que reafirma mensagens políticas de interesse para o regime.

${ }^{10}$ FERRO, M. O filme: uma contra-análise da sociedade?. In: LE GOFF, J.; NORA, P (Org.). História: novos objetos. Rio de Janeiro: Francisco Alves, 1976.

${ }^{11}$ ROSENSTONE, R. History on Film/Film on History. Harlow: Pearson, 2006. 
Sorlin afirma que cada detalhe e passagem, historicamente correta ou não, é conscientemente produzida, interessada e tem a dizer sobre a visão do passado de um grupo. ${ }^{12}$ Segundo Ferro, essas inconsistências históricas constituem lapsos a serem analisados. Por mais apologético que possa ser, o cinema não atinge a condição de propaganda.

'Instrumento' de propaganda, é o que dizia Trotsky, mas essa palavra é fraca, e a chave do problema está justamente aí. Como seus homólogos ocidentais, os dirigentes soviéticos veem ainda no cinema uma "máquina". Tendo herdado da burguesia - sua classe de origem - os mesmos preconceitos, eles têm em relação ao cinema a atitude condescendente que as pessoas "cultivadas" têm em relação àquilo que é "técnico" e, ao mesmo tempo, um prazer popular. ${ }^{13}$

Sem dúvida esse não era o caso de Pudovkin. Alguns cineastas, como Chiaurelli, procuravam transformar suas películas em propaganda, como forma de aproveitamento pessoal do sistema cinematográfico do país. Era uma forma de se fazer carreira. Os cuidados com as metáforas de Pudovkin levaram a mutilação pela censura de um filme posterior, Almirante Nakhimov, de 1946. Entretanto, por saber jogar com as regras do jogo, o diretor conseguiu evitar a proibição da obra. O que Eisenstein, ao ser inflexível, não conseguiu com Ivã o Terrível, parte II, apesar da ajuda de Grigori Alexandrov (1903-1983), que possuía experiência em driblar a censura, equilibrando crítica e elogio (tática que seria pressionada no pós-guerra em nome da adesão e engajamento por completo, requeridos pelo regime na Guerra Fria).

Concluindo, diretores, roteiristas, atores e gerentes soviéticos não podem ser compreendidos como meros propagandistas, ou por dicotomias como engajados-dissidentes, cooptados-opositores. Alguns diretores atacaram medidas tomadas por Stalin, ou a representação oficial da realidade do país, e acabaram mortos no paredão, como o ministro do cinema, Boris Shumiatsky ${ }^{14}$ ou nos gulags, como a diretora Margarita Barskaia ${ }^{15}$. Explicações como as de Miller, baseada nas políticas de cooptação e repressão do Estado, deixam de perceber a agência dos produtores. Uma melhor compreensão poderia ser alcançada por meio da noção de arena, com interesses em conflito. ${ }^{16}$

\footnotetext{
${ }^{12}$ SORLIN, P. La storia nei film. Firenze: La Nuova Itália, 1984, p.19.

${ }^{13}$ FERRO, 1992, p.28.

${ }^{14}$ MILLER, J. Soviet cinema. Londres: IB. Tauris, 2010, p.83.

${ }^{15}$ KENEZ, 1992, p.153.

${ }^{16}$ THOMPSON, E. P. Costumes em Comum. São Paulo: Cia. das Letras, 1998.
} 


\section{HISTÓRIA POLÍTICA E MILITAR REVISTA PELO KREMLIN}

Inicialmente, a concepção de história feita pelo regime era a de que a URSS era um mundo novo, sem tradições, amarras e pendências com o passado. Uma nova etapa se iniciara, sem que existissem relações com velhas estruturas e mentalidades. O passado era a terra do poder pessoal dos czares, da rapina dos boiardos, da opressão mental da Igreja, da sujeição do mujique e do proletário. A história das guerras e das armas russas era a história das guerras imperialistas de 1904, ou de 1914-17, ou entre as atrasadas nobrezas do Leste da Europa e com os decadentes sultões e xeiques muçulmanos da Turquia e Ásia Central. O Exército Vermelho e o Kremlin sob os bolcheviques não possuíam quaisquer relações com esse mundo. Pelo contrário, vieram para destruí-lo.

No entanto, na década de 1930, o retorno da tradição era algo palpável, dos casamentos entre diretores com filhas da nobreza caída ou das relações de trabalho com fraseologia servil, como lembra Trotsky, ao retorno da religiosidade; de uma nova visão sobre o caráter sagrado da família, culminando na abolição do aborto, antes liberado desde a Revolução de Outubro; uma nova definição da imagem e do papel da mulher, não tão igual ao homem (BROWN, 2010, p.68-70); à posição e a função da URSS no mundo, restabelecendo relações diplomáticas e, dentro do possível, comerciais, com os países capitalistas. Esse processo lento de normatização social, ou de arrefecimento do ímpeto revolucionário, se fez sentir por toda a década, em meio ao aumento da desigualdade, com uma maior diferenciação salarial segundo a função, à aplicação da disciplina nos locais de trabalho e fora deles, ao culto do líder. 
Figura 2. O esforço coletivo da travessia dos Alpes como lembrança do trabalho da nação sob Stalin

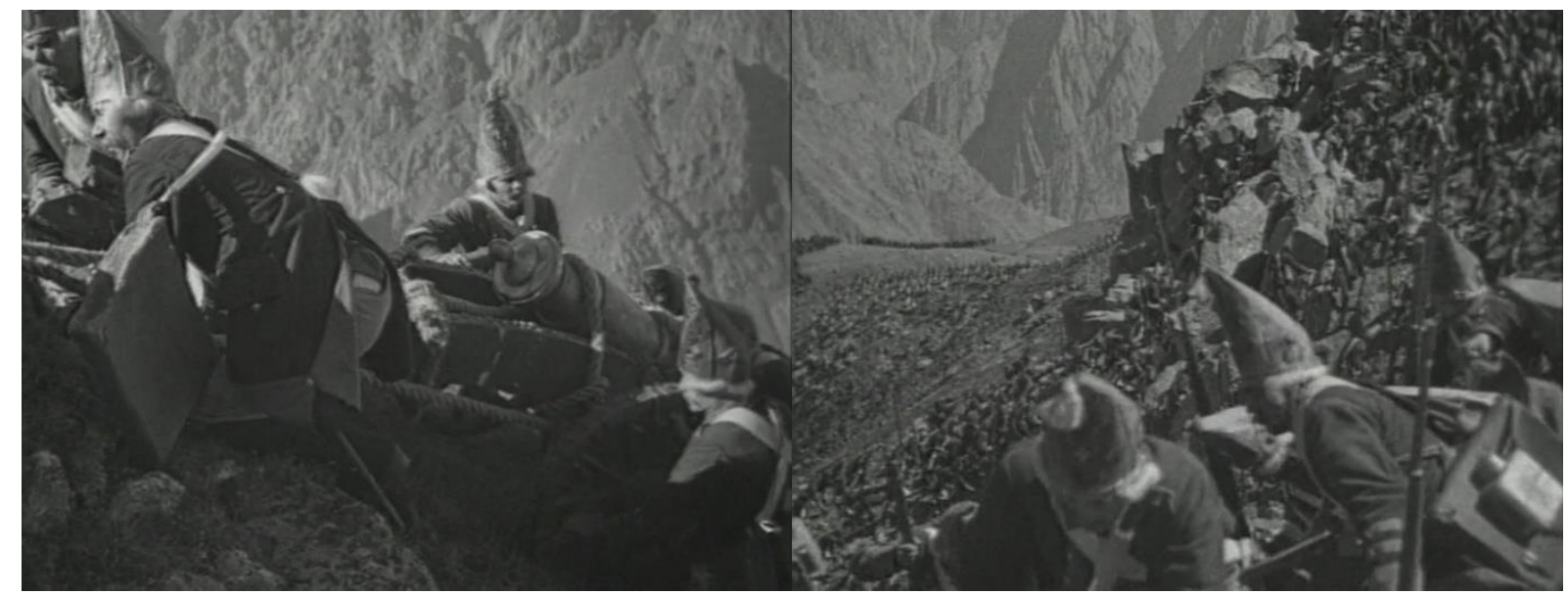

Fonte: SUVOROV, 1940.

Invariavelmente a história necessitava ser reescrita. A Guerra Russo-Japonesa passara a ser lembrada de maneira positiva, especialmente pelo desprendimento dos marinheiros, como os do encouraçado Variag. O exército e a marinha da URSS foram vistos como herdeiros das forças vitoriosas da Rússia dos czares, quando não uma continuação direta destas. Da mesma forma a liderança do Kremlin foi retratada como continuadora da construção do Estado Russo, agora numa nova etapa Soviética. Stalin foi associado com czares como Ivã IV, o Terrível, ou Pedro I, o Grande. Vladimir Petrov dirigiu um filme sobre o último em 1937. Alexei Tolstoi publicara um romance histórico sobre o czar modernizador, e sua luta contra os invasores estrangeiros. $\mathrm{O}$ nacionalismo russo apagou passagens tradicionais da história, por exemplo, atribuindo a origem do Estado russo, a Rússia de Kiev, não mais a vikings, mas a grão-russos autóctones. A onda conservadora dos anos 1930 remodelou as relações entre Estado e Igreja Ortodoxa. A demolição de igrejas terminou, logo após a dinamitação da Catedral de Cristo Salvador, em Moscou, que era um monumento à memória das elites russas czaristas, já que nela apenas seus filhos eram batizados. Nesse mesmo ano, 1936, o Estado permitiu que se erguessem novas igrejas em Moscou $^{17}$. A Rússia profunda, provincial e tradicionalista retornava

\footnotetext{
${ }^{17}$ Werth aponta a mudança de comportamento do regime com a Igreja Ortodoxa: "O estabelecimento de relações corretas e até aparen temente cordiais com a Igreja era um dos imperativos da política do governo soviético desde o início da guerra. Mesmo antes, particularmente após a publicação da Constituição "de Stalin" em 1936 - que assegurava a liberdade de crença religiosa - as formas mais rudes de propaganda antirreligiosa foram abandonadas. Como [...] o desaparecimento do semanário ateu Bezbozhnik, de Emelian Yaroslavsky, na quinzena posterior à invasão alemã" (WERTH, 1966, p.467).
} 
lentamente, emaranhando-se e impondo-se no projeto original dos revolucionários cosmopolitas. ${ }^{18}$

\section{AS REFORMAS DE 1942}

A derrota, com pouca resistência soviética em Rostov, em 28 de julho de 1942, logo após a batalha heroica em Sebastopol, incutiu na opinião pública da URSS um desespero com os fracassos consecutivos e um aborrecimento com o desempenho do exército. Era o momento necessário para uma campanha pública do Kremlin. O clima era o de que a pátria estava em perigo, que não havia para onde mais retroceder, que restava apenas lutar sem ceder terreno. Em agosto iniciava a batalha de Stalingrado.

Obras de divulgação, como Brown, ${ }^{19}$ que aborda toda a história dos regimes comunistas, e mesmo extensas enciclopédias militares, como os onze volumes da Segunda Guerra Mundial, de Gibelli, ${ }^{20}$ mencionam as reformas do Exército Vermelho como necessidades naturais em meio ao calor da batalha - e da derrota. Era necessário livrar a tutela dos oficiais da orientação não profissional dos comissários, além das frequentes disputas paralisantes dentro desse sistema de controle dual militar-político, que acarretavam atrasos nas decisões, comandos dúbios ou modificados em meio às operações. Pelo contrário, as reformas inscrevem-se não na pressão antipolítica e profissionalizante da guerra e dos recuos frente ao inimigo, mas ao processo geral de retorno do conservadorismo na sociedade soviética nos anos 1930. A proximidade da guerra, percebida por Stalin, impeliu algumas decisões. Porém, em 1940, acreditava-se ainda que esta poderia ser atrasada em, no mínimo, um ano. O poder do partido já se encontrava em refluxo frente ao do governo, para onde Stalin removeu seus principais comandos. ${ }^{21} \mathrm{~A}$ experiência desastrosa da Guerra de Inverno com a Finlândia, no fim de 1939 e início de 1940, pode ser considerada como mais um fator para a revisão da organização do exército. ${ }^{22}$ Todavia, meses antes, a estrutura de poder dual poderia ser louvada

\footnotetext{
${ }^{18}$ LEWIN, M. O século soviético. Rio de Janeiro: Record, 2007.

${ }^{19}$ BROWN, A. The Rise and Fall of Communism. Londres: HarperCollins, 2010

${ }^{20}$ GIBELLI, N. A Segunda Guerra Mundial. Vol. 3. Rio de Janeiro: Codex, 1966, p.22-24

${ }^{21}$ LEWIN, 2007.

22 WERTH, Alexander. A Rússia na Guerra. Rio de Janeiro: Civilização Brasileira, 1966.
} 
pela rapidez e eficiência em se retomar a Bucovina e a Bessarábia da Romênia e, em setembro de 1939, a faixa oriental da Polônia, povoada por russos, bielorrussos e ucranianos. ${ }^{23}$

No dia 9 de outubro de 1942, o Presidium do Soviete Supremo emitiu nova ordem, que eliminava o controle dos comissários políticos sobre os oficiais do exército. Afirmava que o trabalho de formação exercido pelos comissários já estava realizado. "Uma enorme quantidade de novos e experimentados oficiais surgira. Adquiriram uma grande experiência. Provaram a sua devoção para com o país e amadureceram, tanto militar como politicamente". ${ }^{24}$ Os quadros do partido, compostos por comissários, poderiam ser transformados em elementos do exército, quando com experiência de combate, como oficiais dos novos grupos de combate formados incessantemente. A liberdade de ação dos militares foi ampliada, não só com a nova extinção dos comissários, como também com a menor interferência de autoridades políticas na condução da campanha.

Oferecer dragonas diferenciadas e insígnias douradas no uniforme dos oficiais não parece ser uma reorganização militar, apenas uma variação nos mesmos uniformes. Porém, isso tocava num ponto nevrálgico da visão dos militares desde a Revolução de Outubro: agora os oficiais distinguiam-se dos praças. A mudança visual possuía implicações profundas, como o retorno da hierarquia comum aos exércitos do resto do mundo ou mesmo à tradição czarista como o estilo das dragonas apontava. O exército deixava de ser, ideologicamente, composto por camaradas para ser dividido entre soldados e superiores, extinguindo a noção de igualdade.

Finalmente, as alterações pós-Rostov marcaram o início da ascensão do status dos oficiais do Exército Vermelho. Novas condecorações foram criadas exclusivamente para oficiais: as Ordens de Suvorov, Kutuzov e Alexandre Nevsky - significativamente denominadas, depois, os "Grandes Ancestrais". Isto constituía parte da campanha promocional que em breve assumiria proporções espetaculares, originando como que uma nova casta de militares, homens a um tempo muito competentes, elegantes e de conjunto agradável aos olhos. O "velho

\footnotetext{
${ }^{23}$ A Linha Curzon, formulada pelo marquês George Curzon, diplomata inglês, estabelecia uma fronteira étnica entre a Rússia soviética e a recém-emancipada Polônia. Os poloneses, no entanto, desejavam suas fronteiras mais ao leste, já que no início do século XVII chegaram a ocupar Moscou por um curto espaço de tempo. A Guerra Russo-Polonesa de 1920 terminou com a derrota russa já às portas de Varsóvia, com o marechal Piłsudski, futuro ditador polaco, cortando as estendidas linhas de suprimentos russas. A nova fronteira ocupou territórios antes pertencentes à Bielorrússia e à Ucrânia. O fator primordial para Stalin não reconhecer o governo Sikorski em Londres, criando um governo popular pró-URSS, foi a negativa da Polônia de devolver essas áreas, mesmo liberadas dos alemães pelos soviéticos (VOLKOGONOV, Dmitri. Stalin: triunfo e tragédia. Rio de Janeiro: Nova Fronteira, 2004; WERTH, 1966).

${ }^{24}$ GIBELLI, 1966, p.23.
} 
cabo-de-guerra", desleixado na sua indumentária e profissionalmente "largado" era cada vez mais desacreditado pelo rumo da propaganda. Dentro em pouco, a dualidade oficial-comissário seria novamente riscada do livro em favor do “comando único" daquele.

No clímax da batalha de Stalingrado foram restabelecidas as ombreiras e alamares de ouro - as ombreiras que os soldados rancorosos arrancaram dos ombros dos oficiais em 1917. Da fumaça e do fogo de Stalingrado emergiram os oficiais com os seus dourados, que brilhavam como as chamas da batalha. $\mathrm{E}$ foi isto que os tornou tão aceitáveis e populares. Sua reinstituição teve o sabor de um prêmio a todo o oficialato soviético. Representava ainda a profissionalização do Exército Vermelho, que não era mais a força revolucionária de sans-culottes; aproximavase a era em que a sua palavra seria ouvida como a do grande exército nacional da Europa e os seus oficiais tinham o direito de vestir-se com o mesmo garbo dos ingleses e americanos - para não falar dos alemães. Psicologicamente, foi ótimo que os enfeites surgissem da batalha de Stalingrado, e não antes, porque a beleza dos uniformes não condiz com as retiradas [...].

Pouco depois, em 1943, surgiu um novo código de conduta para os oficiais; por exemplo, acima de um certo posto não podiam mais viajar em transportes públicos nem "carregar embrulhos". Revivia-se parte da etiqueta do Exército Tzarista. ${ }^{25}$

Medalhas com os nomes de Suvorov e Kutuzov, os grandes generais do período napoleônico, já existiam sob o regime dos czares. A Ordem de São Alexandre Nevsky existiu sob o último czar, Nicolau II. Desse modo, também se tratava de uma retomada do passado nobiliárquico. O Pravda publicava a manchete "Santa Rússia", no começo de julho, para relatar os últimos momentos da defesa de Sebastopol.

O aumento da moral com o retorno de antigas aparências exteriores não afetou apenas os oficiais. Os alemães diziam que os soviéticos sequer pareciam soldados com o uniforme sem distinções, ombreiras, dragonas, e todos os sinais característicos dos uniformes militares. Possuíam um aspecto civil - ou popular, sob a ótica dos revolucionários de 1917, que arrancavam de suas túnicas esses símbolos. A mudança profunda era uma cisão entre um antigo

${ }^{25}$ WERTH, 1966, 452-453; 466. 
exército de operários e camponeses e uma tropa nova e moderna formada por profissionais, quase uma classe à parte.

A arte foi mobilizada para o esforço moral. Poetas e prosadores como Simonov, que era oficial militar, já publicavam no Krasnaya Zvezda, Estrela Vermelha, o jornal do Exército Vermelho. Porém, a partir da segunda metade de 1942, outros nomes importantes da literatura soviética passaram a participar do periódico. Alexei Tolstoi, Ehrenburg, homem do partido, e Sholokhov, Nobel de literatura de 1965. As poesias de Simonov costumavam ser construídas a partir da posição do oficial - como é o caso de sua obra mais famosa, Os vivos e os mortos, já no pós-guerra. Outros exploravam a ótica do soldado, como Surkov. A obra teatral A frente, de Korneichuk, foi composta nessa época, com a sugestão do roteiro básico feita pelo próprio Stalin. ${ }^{26}$ Se a historiografia mais distanciada do cenário soviético estivesse certa ao demarcar o processo de reformas como puro impacto da derrota do verão de 1942, seria este o momento da produção de Suvorov, e não 1940.

\section{AS REFORMAS DE 1940}

A Guerra de Inverno terminou em 12 de março de 1940. Concomitantemente, a URSS vira a Alemanha se apoderar da Dinamarca e da Noruega com extrema facilidade. A primeira reforma ocorreu em 8 de maio de 1940. O Presidium do Soviete Supremo restaurou o cargo de marechal da URSS (concedido, naquele momento, a Voroshilov, Timoshenko, Kulik e o antigo coronel do exército czarista que tornou-se uma das maiores mentes militares do país, Shaposhnikov), criou novos, como Major-General, Tenente-General e General de Exército, para desenvolver a hierarquia e a ordem de comando no exército, com a supressão do antigo cargo de Comandante de Exército de Primeira Classe. O mesmo aconteceu na marinha soviética. Na prática, significava a restauração de antigos postos czaristas, usuais no mundo capitalista. Seguiu-se uma campanha nos meios de comunicação. ${ }^{27}$

\footnotetext{
${ }^{26}$ WERTH, 1966, p.447-451; 460.

27 "Nos meses que se seguiram, as páginas dos jornais se encheram de nomeações e promoções, ilustradas pelos retratos dos novos generais. Quatro páginas do Pravda foram assim ocupadas. Esta vasta publicidade concedida a centenas de generais do Exército Vermelho, logo após a invasão da França pela Alemanha, destinava-se, efetivamente, a criar no público uma sensação de segurança" (WERTH, 1966, p.105).
} 
Uma nova rodada de transformações organizacionais ocorreu em agosto do mesmo ano. O comando único das tropas, em desuso desde os tempos czaristas, fez sua reaparição. Segundo o general Zukhov, grande defensor da reorganização, em entrevista de 23 de fevereiro de 1941, no Pravda, "a situação, a responsabilidade e a autoridade dos oficiais melhorou enormemente”. Previa-se a alteração de todo o programa curricular e do sistema de educação e treinamento nas escolas de formação de oficiais, fortalecendo o viés técnico-profissional em detrimento do político. O general ainda lembrava que estas eram apenas mudanças fundamentais de orientação, que seriam acompanhadas de muitas outras. ${ }^{28}$ As mudanças organizacionais no ensino não foram implementadas de todo antes da eclosão da guerra. O norte das transformações militares na URSS, que culminaria em 1942, com a adoção de antigas fórmulas rejeitadas pela Revolução e da organização recorrente no resto do mundo, já estava dado antes da Grande Guerra Patriótica.

A decisão de preconizar o pragmatismo à ideologia ganhava corpo na União Soviética. Stalin partilhava dessa premissa na maioria das vezes. Apesar da insistência de seus aliados Budyonny e Voroshilov, principais nomes no exército até o fim de 1941, manteve suas dúvidas quanto à superioridade da cavalaria na guerra moderna e do uso dos blindados como parte de corpos de infantaria e não como grandes unidades independentes. Porém, os relatórios do general Pavlov, enviado à Espanha durante a guerra civil para analisar o desempenho dos tanques soviéticos vendidos ao governo da República Espanhola, deram parecer favorável aos usos antiquados dessas forças. ${ }^{29}$ Impressão que foi reforçada com o fracasso da penetração dos tanques em meio as florestas nevadas no norte da Finlândia.

Da mesma forma, ocorreu o retorno do nacionalismo, ao mesmo tempo em que se procurava equilibrá-lo com o internacionalismo. As fronteiras soviéticas foram consideradas sagradas na década de 1930. O nacionalismo possível na URSS era o grão-russo, ou eslavo, que aglutinava as três maiores nacionalidades naquele momento: a russa, a ucraniana e a bielorrussa, que compartilham idiomas quase idênticos. Não existiam ainda urbanização e educação nos níveis propícios a gerar a identidade e o sentimento nacionais nas Repúblicas da Ásia Central - apesar da obrigatoriedade do ensino da língua e literatura locais, fatores que desenvolveriam

\footnotetext{
${ }^{28}$ WERTH, 1966, p.142.

${ }^{29}$ VOLKOGONOV, Dmitri. Stalin: triunfo e tragédia. Rio de Janeiro: Nova Fronteira, 2004, p.383.
} 
esses sentimentos posteriormente. Com a guerra e a fraquíssima resistência da Ucrânia ocidental aos invasores ${ }^{30}$.

A guerra não deve ser entendida como provocadora dessa mudança ideológica na URSS. Sequer pode ser concebida como catalisadora desse processo. As reformas de $1942 \mathrm{em}$ boa medida apenas reeditaram as de 1940. A guerra serviu inicialmente como fator de reversão. A retirada desorganizada frente ao inimigo, em especial nos meses de junho e de setembro de 1941, fez com que o partido visse com desconfiança as lideranças militares, frequentemente levadas a julgamento ou remanejadas. Optou-se pela imposição novamente da presença dos comissários políticos ao lado dos oficiais militares. A continuidade da retirada do Exército Vermelho em 1942 demonstrou a liderança que havia se equivocado, reconduzindo o processo de reforma ao seu antigo eixo.

Se Stalin fosse bem-sucedido em isolar o país da guerra, a separação final entre o corpo de oficiais como uma classe, ou mais precisamente, um estrato, distinto dos demais, e em especial dos soldados, teria demorado mais a se processar. Por que Stalin profissionalizou um órgão tão importante para a segurança de uma ditadura? O exército fora esvaziado de oposicionistas ou figuras não confiáveis pelos expurgos de 1937-38 ${ }^{31}$. Aqueles que ocuparam as cadeiras vagas não possuíam qualquer ligação com Trotsky, Bukharin, as oposições de direita ou de esquerda. Pelo contrário, deviam sua ascensão à Stalin. Uma reforma desideologizante nas academias militares não eliminava a formação partidária de oficiais e aspirantes.

\footnotetext{
${ }^{30} \mathrm{O}$ argumento de que a falta de bosques propícios ao trabalho guerrilheiro foi a razão da falta de apoio da Ucrânia Ocidental não parece ser válido, uma vez que as guerrilhas de nacionalistas pró-fascismo, que haviam prestado serviços militares e de controle civil aos ocupantes nazistas, vicejaram na região durante o contra-ataque soviético e além, até 1947, sendo responsáveis até pela morte de um dos mais destacados generais soviéticos durante a guerra, Nicolai Vatutin, libertador de Kiev (POSPELOV, P. La Gran Guerra Patria de la URSS. Progreso: Moscou, 1975.).

${ }^{31}$ Os expurgos impunham igualmente a profissionalização. Apesar de se concentrarem sobre comissários políticos na estrutura militar, ainda assim representou a destruição da formação técnica dos quadros das forças armadas. "De maio de 1937 a setembro de $1938,36.761$ homens foram expurgados do exército e mais de 3 mil da marinha [...]. Como resultado da repressão, foram afastados todos os comandan tes de distritos, $90 \%$ dos chefes e vice-chefes dos estados maiores regionais, $80 \%$ dos comandantes de corpos e divisões e $90 \%$ dos oficiais de estado-maior. A consequência foi uma sensível queda na qualidade intelectual dos oficiais. No início de 1941, somente $7 \%$ dos oficiais em comando tinham frequentado uma escola de altos estudos militares, 55,9 só tinham formação secundária, 24,6\% haviam sido formados em cursos comprimidos e $12 \%$ dos oficiais e do pessoal político não tinham qualquer instrução militar" (VOLKOGONOV, 2004, p.384). O ímpeto profissio nalizante não foi o suficiente para reabastecer as tropas. Com a eclosão da guerra, Stalin se viu na necessidade de retirar muitos desses expurgados da aposentadoria compulsória ou do campo de trabalho, como o general Rokossovsky.
} 


\section{SUVOROV: O CINEMA ENTRE AS DEMANDAS DO REGIME E A LIBERDADE ARTÍSTICA}

A revisão histórica culminou com a identificação plena do regime com os heróis czaristas. Iniciada na década de 1930, foi aprofundada com a guerra. Pedro I (1937), de Vladimir Petrov (1896-1966) ${ }^{32}$, apesar de ser laudatório com a construção do Estado Russo pelo czar modernizador, não o deixa de representar como um nobre arrogante, que não permite sequer ser olhado diretamente por seus pares nobres, e ainda mais distante das massas. Não é uma visão inteiramente positiva para o regime socialista, mantendo certa distância com o retratado. Em 3 de julho de 1941, no primeiro discurso radiofônico feito por Stalin após o ataque nazista, faz-se a aproximação entre as derrotas infringidas a Napoleão e o Kaiser Guilherme ao passado nacional. Essa identificação com o passado antes renegado atinge o clímax em 7 de novembro de 1941, com sua fala do alto do sarcófago de Lenin, abrindo o desfile do Exército Vermelho na comemoração do Grande Outubro, quando Moscou parecia prestes a ser cercada:

Os povos escravizados da Europa, sob o jugo dos invasores alemães, veem-nos como libertadores. Uma grande missão libertadora lhes é atribuída. Sejam dignos dessa missão. A guerra que vocês travam é uma guerra libertadora, uma guerra justa. Para essa guerra, inspirem-se no glorioso exemplo de nossos grandes ancestrais: Aleksandr Nevski, Dimitri Donskoi, Kuzma Minin, Dimitri Pojarski, Aleksandr Suvorov, Mikhail Kutuzov ${ }^{33}$ ! Que a bandeira vitoriosa do Grande Lênin os una sob seu pendão. ${ }^{34}$

Anteriormente Stalin citara esses personagens históricos do passado russo, mas sempre os arrolava ao lado de heróis bolcheviques, como Chapayev. Em outros discursos haveria espaço até pra Brusilov, o general de Nicolau II que conseguiu em 1916 o último avanço russo na Primeira Guerra. O discurso de 7 de novembro marca uma ruptura, ao não constar nenhuma

\footnotetext{
32 A nova possibilidade de realizar filmes sobre personagens czaristas como protagonistas levou Pudovkin a sugerir a produção de Suvorov ainda em 1938, porém foi liberado um ano depois (MILLER, 2010, p.45).

${ }^{33}$ Dimitri Donskoi (1350-1389) foi o primeiro príncipe da Moscóvia a enfrentar a Orda Dourada dos tártaros mongóis que fizeram as Rússias medievais suas tributárias. Kuzma Minin (1570-1616) foi um cidadão, comerciante, que se destacou na expulsão dos poloneses de Moscou, durante a Guerra Polonesa-Moscovita (1605-1618) e na condução da nova dinastia Romanov ao trono. Dimitri Pozharski, príncipe da antiga dinastia Rurik, vikings fundadores da Rússia de Kiev, destronados em 1598, combateu ao lado de Minin. Ambos representam a união nacional, pela diferença de nascimento e fortunas (PERRIE, M.; LIEVEN, D.; SUNY, R. G. (Org). The Cambridge History of Russia. Cambridge: Cambridge University Press, 2006).

${ }^{34}$ MARCOU, L. A vida privada de Stálin. Rio de Janeiro: Zahar, 2013, p.177.
} 
personalidade da nova Rússia soviética. Durante a crise de Stalingrado, outro discurso de tom histórico nacionalista foi elaborado pelo chefe de partido e chefe de governo. Novamente apenas heróis czaristas foram lembrados. Suvorov foi reabilitado pela imprensa soviética ainda em 1937, ao ser descrito como "herói popular", ao mesmo tempo em que era "instrumento da política czarista na Europa e gendarme da política europeia". ${ }^{35}$ Em 8 de fevereiro de 1940 alguns dos maiores cineastas soviéticos, como Eisenstein e Yutkevich, participaram de uma conferência que debateu e estabeleceu diretrizes para os filmes históricos. ${ }^{36}$

Suvorov marca um estágio intermediário desse processo. Como aponta Dobrenko, entre o início e o fim dos anos 1930, o cinema passou dos louvores aos militares "filhos de Chapayev" aos "netos de Suvorov". 37 O protagonista teve realçadas ou acrescentadas características que poderiam aproximá-lo da ideologia oficial. A residência exibida na película era em seu exílio, no norte da Rússia, na aldeia de Konchanskoe, perto de Novgorod, e não sua residência principal. Uma casa de madeira parecida com as cabanas dos camponeses ambientação certamente inspirada no quadro de Geller, Suvorov em desgraça. O conde Suvorov (interpretado por Nikolai Cherkasov ${ }^{38}$, nascido Nikolai Sergeev, de família nobre e sem qualquer parentesco com Nikolai Cherkasov, ator que interpretou o czar em Ivã, o Terrível, de Eisenstein) é igualitário. Louva seus soldados chamando-os por heróis, águias, bravos, irmãos. Faz os oficiais comerem com colheres de pau juntamente com a tropa. Seu lugar é ao lado desta. Eleva simples soldados a posição de coronéis e degrada oficiais de nascimento, segundo a eficiência. Recebe seus veteranos no exílio e os transforma em valetes. Quando no mundo da corte ou ao lado de outros oficiais, seu mundo se desvanece, aturdido por intrigas. O príncipe Pyotr Bagration (Sergey Kiligin), da família real georgiana, companheiro de Suvorov e futuro herói da campanha de 1812, teve o caráter alterado. Tornou-se, apesar de nobre, em um soldado com sentimentos populares, compartilhados com seus homens. O contraste perfeito com o conde Alexey Arakcheev (Mikhail Astangov), protótipo da nobreza cortesã, afetada, dada à intriga, elevada à carreira militar, transformando o exército numa exibição palaciana esdrúxula. Substitui uniformes práticos por "ridículas fantasias", o treinamento pelos desfiles.

\footnotetext{
35 BRANDENBERGER, D. National Bolshevism: Stalinist mass culture and the formation of modern Russian national identity, 1931 -1956. Cambridge: Harvard University Press, 2002, p.99.

${ }^{36}$ LEYDA, J. Kino: a history of the Russian and Soviet film. Princeton: Princeton University Press, 1983, p.363.

${ }^{37}$ DOBRENKO, E. Stalinist cinema and the production of history. Edinburgo: EUP, 2008, p.69.

${ }^{38} \mathrm{O}$ ator condizia com o biotipo de Suvorov, que "parecia um espantalho esfarrapado, magro e eriçado" (MONTEFIORE, Simon Sebag. Os Románov: 1613-1918. São Paulo: Companhia das Letras, 2016, p.314).
} 
Bazin estipula o caráter do herói histórico no cinema soviético. ${ }^{39}$ Ele não se define por aspectos psicológicos e comportamentais, mas sim políticos. Pode ser desregrado, saqueador, um “traste". Mesmo assim será um herói se segue a linha política correta: Chapayev, no filme homônimo de 1934, luta primitivamente, com táticas da "cavalaria medieval”, é conturbado, porém começa a compreender e a obedecer ao comissário político Furmanov, consequentemente, ao partido. Pedro I, o Grande, no filme de mesmo nome de 1937, apesar da beberagem e de toda a arrogância aristocrática, é patriota e evidencia a importância da lealdade. A linha seguida por Suvorov é a da defesa do Estado. Bazin aponta que uma diferença marcante entre o cinema soviético e o americano era o caráter humano do herói histórico - nada daqueles personagens sem dúvidas, incorrigíveis, representando o bem absoluto. O autor escreveu em 1950 e, em ambos os países, tal situação mudava lentamente. Suvorov não é marcado por nenhuma mancha ou ação condenável. Situação que se estabeleceria de vez no cinema da URSS do pós-guerra até a morte de Stalin. Não se pode tomar por fator negativo sua indisciplina, pois ela se dirige apenas ao fraco e fantasioso czar Paulo I, se referindo muito polidamente à antecessora, Catarina II, a Grande. Nem, tampouco, sua religiosidade como negativa.

O diretor aprimora o roteiro em detrimento da história. A batalha da Ponte do Diabo ocorreu no começo da Campanha Suíça (14 de setembro de 1799), e não no final. Ao mudar a cronologia, Pudovkin transforma a retirada de Suvorov dos Alpes em uma vitória, mantendo o clima otimista requerido pelo realismo socialista. Também mantém a estrutura do roteiro girando em torno do ciclo fama-depreciação-consagração do marechal. Suvorov, ao fim da campanha (outubro de 1799) perdera $1 / 4$ de seus homens. $O$ filme se inicia com a tomada do campo de Sokolkino. Esta batalha, no entanto, nunca existiu, mas pode se presumir que se passe durante a Revolta de Kosciuszko, de 1794. Ela reúne vários elementos da carreira do conde: travessia em velocidade de terrenos considerados instransponíveis (florestas e pântanos) para atacar o inimigo de surpresa pela retaguarda, a dificuldade de relações com outros oficiais adeptos de métodos cautelosos, a proximidade com a morte (seu cavalo é morto, mas ele sai ileso). Mas nem tudo se submeteu ao roteiro ${ }^{40}$. Pudovkin não o elaborou sozinho. Foi escrito

\footnotetext{
${ }^{39}$ BAZIN, André. O mito de Stálin no Cinema Soviético. In: BAZIN, André. O que é o Cinema? São Paulo: Cosac Naify, 2014 , p.64. ${ }^{40}$ Certamente Pudovkin gostaria de mostrar a Inglaterra como uma aliada tão temerosa quanto a Áustria, como no desembarque anfíbio conjunto na Holanda, quando a Rússia se queixa da pouca vontade inglesa, ou quanto estes invadem Malta, protegida por Paulo I, e quase levam a Rússia a formar uma aliança continental com Napoleão. Ou mesmo a influência inglesa no assassinato do czar. Esses acontecimentos, no entanto, se deram após a morte do marechal Suvorov, em 1800 (PERRIE; LIEVEN; SUNY, 2006). Montefiore (2016, p.343) se equivoca ao falar da ira de Paulo com a ocupação por Napoleão de Malta, em 1798. Ele tornou-se grão-mestre apenas após o fato.
} 
originalmente pela dupla Georgiy Grebner e Nikolai Ravich. Além de outro importante cineasta: Mikhail Romm (1901-1971). Romm planejou o roteiro de forma a realçar a ousadia e excentricidade do marechal em meio à vida da corte. Um fator a mais, o do humor, para o entretenimento do público. Romm o definiu como um novo gênero, a "comédia heroica". ${ }^{41}$ Para as locações, o diretor escolheu as altas montanhas do Cáucaso. ${ }^{42}$

O cinema soviético possuía a característica peculiar de usar em muitas vezes dois diretores. É o caso também de Suvorov. Mikhail Doller (1889-1952), diretor e roteirista, amigo de Pudovkin, ficou com o cargo de co-diretor. Função que exercia em todos os filmes de Pudovkin desde 1927. A relação entre ambos, em Suvorov, no entanto, não foi das melhores. Ivan Bolshakov, ministro do Cinema, pediu alterações no roteiro, alertando aos dois diretores e ao produtor da Mosfilm que a visão das conquistas territoriais czaristas como a construção de uma "Rússia prisão de nações" não era recomendável. O enfoque pró-polonês das cenas iniciais foi substituído por um ponto de vista estritamente militar. Jornais soviéticos da época criticaram a ênfase na individualidade de Suvorov, ou sua excentricidade, como chave para o seu sucesso. $^{43}$

Um filme dedicado a história militar poderia fazer sugestões com a Antiguidade, relacionando Suvorov como um novo Aníbal, de forma laudatória. Essa referência não ocorre. Pelo contrário, é o esforço coletivo do exército russo que é ressaltado, com o auxílio mútuo entre os soldados para cruzar corredeiras geladas, içar canhões entre montanhas, subir escarpas, caminhar sobre rochedos, o que pode ser visto como uma recriação da visão oficial sobre os projetos de industrialização acelerada e coletivização agrícola da década recém findada, agora lançada sobre o passado do país.

Suvorov poderia ter sido visto sob a ótica das batalhas vencidas na Polônia, como contra o general francês renegado Dumouriez. Mas essas batalhas mal são citadas. Poderia ter sido visto sob a ótica do administrador, ao evitar a peste na Criméia, gerenciada por ele naquele momento (1778), impondo o banho, a higiene urbana e a quarentena de viajantes. Ou como pacifista e defensor das fronteiras, evitando uma nova guerra com os turcos ao impedir seu desembarque na costa da Criméia. Todas essas visões seriam agradáveis ao regime. Uma de

\footnotetext{
${ }^{41}$ DOBRENKO, 2008, p.89.

${ }^{42}$ LEYDA, 1983, p.363.

${ }^{43}$ MARSHALL, H. Masters of the Soviet Cinema. Abingdon: Routledge, 2013.
} 
suas campanhas poderia ser até mesmo relacionada com a vida militar de Stalin. Foi chamado para debelar a rebelião de Pugatchev, no Volga, em 1774, formada principalmente por camponeses. Estabeleceu seu quartel-general em Tsaritsin, a futura Stalingrado, hoje Volgogrado. Essas passagens teriam suscitado lembranças ao público das decantadas histórias dos feitos de Stalin e de seus aliados Voroshilov e Budyonny, na vitória sobre os brancos, no mesmo local, em 1919. Além da recente crise com os kulaks. Esse tipo de associação deve ter parecido desinteressante, ou temerosa demais, para Pudovkin.

Morettin (2003) afirma que um filme pode abrigar leituras opostas acerca de certo fato. A percepção desse movimento deriva do conhecimento específico do meio, o que permite encontrar os pontos de adesão ou de rejeição existentes entre o projeto ideológico-estético de um determinado grupo social e a sua formatação em imagem. Žižek demonstrou como uma mesma mensagem pode ser lida de diferentes maneiras dentro de uma mesma plateia. ${ }^{44}$ Filmes como 300 (2006), de Zack Snyder, ou Batman (2008) de Christopher Nolan, acionam interpretações opostas entre pessoas com formação política à esquerda ou à direita. 300, por exemplo, pode ser lido como a vitória da democracia sobre as hordas de cor iranianas, ou como a resistência de um pequeno país frente a um império corrupto, como o americano. Pode ser decifrado até de maneira subversiva, como uma Esparta talibã se insurgindo contra a ocupação ocidental. Parece difícil acreditar que o diretor de 300 possuísse qualquer intenção de facilitar múltiplas leituras. Este não é o caso de Pudovkin.

O diretor possuía o controle sobre a leitura de seu filme? Por mais que o desejasse, como demonstra Ferro (1992), isso é impossível, pelas tensões em sua produção, pelas relações com atores, roteiristas, adaptações forçadas, etc. Brown afirma que filmes críticos ao regime soviético acabaram sendo liberados para a exibição porque o regime considerava que a maioria dos espectadores não seria capaz de decifrar críticas sutis e alegóricas, já que eram assim formuladas, dentro das possibilidades de um regime autoritário que detém o controle financeiro dos estúdios e agências regulatórias e de censura. ${ }^{45}$ Aqueles que poderiam identificar a visão negativa do diretor constituíam um grupo menor, de dissidentes ou opositores que comungavam de um mesmo universo de informações paralelas, não-oficiais. Estes já estavam perdidos para

\footnotetext{
${ }^{44}$ RADOVIC, Stanka. On the threshold: Terrain vague as living space in Andrei Tarkovsky’s Stalker. In: BARRON, P.; MARIANI, M (Org.). Terrain Vague. Nova York: Routledge, 2014, p.121; 90.

${ }^{45}$ BROWN, 2010, p.575.
} 
a propaganda, não significando um problema o seu acesso à película ${ }^{46}$. Chartier elabora melhor esta questão.

O diretor, assim como o escritor, pode exercer influência sobre as leituras individuais de cada leitor, ou espectador, por meio das palavras e conceitos que usa, ou chaves de leitura; pelas características materiais, elementos visuais e tipográficos, elementos textuais e estratégias de escrita, ou protocolos de leitura, ${ }^{47}$ até atingir seu público-alvo, uma "comunidade de interpretação", que compartilha de um mesmo comportamento de leitura e de pensamento, convenções, etc. ${ }^{48}$

Pudovkin contava ainda com a ambiguidade em seu favor. Kaminski demonstra como a alegoria, a metáfora, a dubiedade, a inserção de personagens fictícios em uma trama de fundo histórico, podem revelar as opiniões próprias do diretor sobre o passado representado. ${ }^{49}$ Principalmente em regimes autoritários, que dificultam ou impossibilitam críticas abertas. "Regimes autoritários podem ser vulneráveis a palavras e como palavras bem colocadas são capazes de mobilizar a força misteriosa que conhecemos como opinião pública". 50 A ambivalência permeia Suvorov. Elementos da situação diplomática e militar da URSS de 1940 transparecem no filme. A prudência de Stalin proibia qualquer tensão com a Alemanha nazista. Evitou concentrar as tropas na fronteira até a eclosão da guerra porque lembrava-se que Nicolau II, ao fazê-lo, provocou o ataque do Kaiser, em 1914 (VOLKOGONOV, 2004). A arte foi submetida à mesma necessidade. Apesar de ganhar o Prêmio Stalin e ser um sucesso nas bilheterias soviéticas, Alexandre Nevsky (1938), de Eisenstein, foi retirado de exibição e proibido. O mesmo ocorreu com outros filmes antifascistas, como Shchors (1939), de Dovzhenko, comissionado pelo próprio Stalin.

Pudovkin se vê na difícil situação de recriar antigas tradições do exército e preparar o público para uma guerra iminente, sem, todavia, citar a Alemanha como o inimigo, ou como a

\footnotetext{
${ }^{46}$ Lawton (1992) permite pensar o liberalismo do regime de outra maneira. Afinal, os milhões que compraram ingressos para assistir a Siberiade parecem escapar do campo formado por dissidentes. A autora demonstra que várias técnicas de censura eram aplicadas pelo governo: distribuição pela Goskino de poucas cópias para a exibição, retenção do filme por alguns anos (o que aconteceu com o subversivo Agonia (1981), de Elem Klimov, que apresentava o último czar como um bom homem, sem muito traquejo político, ao contrário do assassino que ordenou a matança de civis no Domingo Sangrento, que constituía a visão da história oficial), baixa adesão dos cinemas às películas polêmicas. O que foi o caso, por exemplo, do próprio Siberiade. As redes de informação informais, como demonstra Lewin (1988), poderiam ser abastecidas e fortalecidas com a liberação desses filmes. O que ia contra as intenções governamentais soviéticas.

${ }^{47}$ CHARTIER, R. Do livro à leitura. In: CHARTIER, R. (Org.). Práticas da leitura. Brasília: Estação Liberdade, 1996, p.77-105.

${ }^{48}$ CHARTIER, R. A história hoje: Dúvidas, desafios, propostas. Estudos Históricos, vol. 13, n.7, p.97-113. Rio de Janeiro, 1994, p.108.

${ }^{49}$ KAMINSKI, R. Da narração literária às telas do cinema: camadas de sentido alegórico em A Guerra dos Pelados. História Questões \& Debates, v. 44, p.87-114. Curitiba, 2006.

${ }^{50}$ DARNTON, R. O diabo na água benta. São Paulo: Companhia das Letras, 2012, p.530.
} 
aliada tácita da divisão da Polônia, da qual Suvorov tomou parte. Assim, apesar de mencionadas as façanhas em "Cracóvia, Turukay, Rymnik, Tocsani, Kinburn e Ismail”, contra os poloneses e os turcos (que durante boa parte da guerra constituíram um temor extra para o Kremlin, ante o risco de uma reedição da aliança com a Alemanha de 1914, expondo o franco do Cáucaso ao seu ataque), elas não são exibidas. O inimigo escolhido é a França Napoleônica. Após o fracasso das tentativas soviéticas de unir Inglaterra e França numa frente antifascista, o que resultou no Pacto de Não-Agressão Nazi-Soviético de agosto de 1939, o caráter dos possíveis futuros aliados não deixa de ser contestado. Os generais austríacos e ingleses da Segunda Coligação Anti-Francesa (1798-1802), que combatem ao lado de Suvorov nos Alpes da República Cisalpina e República Helvética, compartilhariam do medo de seus respectivos governos da expansão da influência russa pela Europa. Por isso pretendem detê-lo, traindo-o frente às tropas francesas comandadas por Andre Masséna (1758-1817), que já desbarata o exército russo de Rimsky-Korsakov (1753-1840). Toda uma sub-trama do filme foi gerada de forma a criar uma metáfora das dificuldades presentes da URSS. A fala do marechal sobre o perigo que Napoleão representa surtia grande efeito sobre o público, já que constituía uma profecia já tida como certa em $1940^{51}$ :

É hora de pará-lo. É o momento... ou será tarde demais. Olhe a direção de seu avanço. Conquistou a Itália e a Áustria... isso não é conquistar nada. Ela mesma jazia aos seus pés. E é aqui que vai disferir outro golpe: Rússia.

Porém ele lançara em vão a Europa contra a Rússia. Aqui encontrará ódio feroz, grande valentia e o seu caixão. ${ }^{52}$

Alexandre Nevsky (1938), de Eisenstein, evidenciou as preocupações soviéticas de ataque em dois frontes: os cavaleiros teutônicos (nazistas - e tão pouco interessado em disfarçar a identificação promovida pelo filme entre ambos que espalha suásticas e mãos em saudação pela indumentária dos cavaleiros) no ocidente e os tártaros (japoneses) a oriente. Em 1938 a tensão com a Alemanha e a Polônia roçou a guerra com a partilha da aliada Tchecoslováquia por ambas (além do parceiro húngaro) e se desenrolou a Batalha do Lago Kashan contra os

\footnotetext{
${ }^{51}$ Ao se negar a aprofundar o tratado de não-agressão com a Alemanha, com a proposta desta de um ataque soviético à Índia Britânica a partir da Ásia Central soviética, e denunciar a violação alemã da soberania dos países balcânicos, os leitores soviéticos sabiam perfeitamente que a relação entre ambos os regimes esfriara, e que a guerra era inevitável num futuro não muito distante (WERTH, 1966).

52 SUVOROV, 1940.
} 
japoneses. Pudovkin usou o tema das Guerras Napoleônicas de maneira menos categórica que Eisenstein para advertir do perigo hitlerista. O tema seria novamente utilizado já durante a guerra, em 1943, por Petrov em seu Kutuzov - grande general russo contemporâneo à Suvorov.

Tabela 1. Crimes comuns e políticos durante a NEP, as purgas dos anos 1930 e a Segunda Guerra

\begin{tabular}{|c|c|c|c|c|c|}
\hline Anos & Condenações & $\begin{array}{c}\text { Sentenças de } \\
\text { morte }\end{array}$ & $\begin{array}{c}\text { Campos, colônias e } \\
\text { prisões }\end{array}$ & Exilados & Outros \\
\hline 1925 & 15995 & 2433 & 6851 & 6274 & 437 \\
\hline 1926 & 17804 & 990 & 7547 & 8571 & 696 \\
\hline 1927 & 26036 & 2363 & 12267 & 11235 & 171 \\
\hline 1928 & 33757 & 869 & 16211 & 15640 & 1037 \\
\hline 1929 & 56220 & 2109 & 25853 & 24517 & 3741 \\
\hline 1930 & 208069 & 20201 & 114443 & 58816 & 14609 \\
\hline 1931 & 180696 & 10651 & 105683 & 63269 & 1093 \\
\hline 1932 & 141919 & 22728 & 73946 & 36017 & 29228 \\
\hline 1933 & 239664 & 2451 & 138903 & 54262 & 44345 \\
\hline 1934 & 78999 & 2056 & 59451 & 5994 & 11498 \\
\hline 1935 & 267076 & 1229 & 185846 & 33601 & 46400 \\
\hline 1936 & 274670 & 118 & 219418 & 23719 & 30415 \\
\hline 1937 & 606650 & 353074 & 429311 & 1366 & 6914 \\
\hline 1938 & 554258 & 328618 & 205509 & 16342 & 3289 \\
\hline 1939 & 63889 & 2552 & 54666 & 3783 & 2888 \\
\hline 1940 & 71806 & 1649 & 65727 & 2142 & 2288 \\
\hline 1941 & 75411 & 8011 & 65000 & 1200 & 1210 \\
\hline 1942 & 124406 & 23278 & 88809 & 7070 & 5249 \\
\hline 1943 & 78441 & 3579 & 68887 & 4787 & 1188 \\
\hline 1944 & 75109 & 3029 & 70610 & 649 & 821 \\
\hline 1945 & 123248 & 4252 & 116681 & 1647 & 668 \\
\hline
\end{tabular}

Fonte: LEWIN, Moshe. O século soviético. Rio de Janeiro: Record, 2007, p.481.

Alguns elementos aproximam Suvorov de uma leitura stalinista, que projeta no personagem imagens do apelo ao trabalho duro, de "acelerar o passo duplicado, triplicado", transpor o que se supunha intransponível, a união dos soldados para a conclusão das metas, etc. Motes caros ao regime. Ao mesmo tempo cumpre sua função de elevar o moral dos militares soviéticos, ao elogiar o espírito de corpo, do exército como uma entidade a parte na sociedade, 
não mais dissolvido entre civis - operários ou camponeses, com uma tradição notável e invejável. O projeto de profissionalização das forças armadas é defendido: Suvorov entra em choque com o czar Paulo I (Apollon Yachnitsky), ou Pavel I, e sua visão de um exército como uma máquina. O que seria impossível, dada a falta de instrução básica ou técnica da tropa, da inexistência do mérito como balizador da carreira do oficialato, da má formação deste. Eram "baionetas que não poderiam ser usadas". No entanto, a ambiguidade pode ser encontrada neste conflito: Suvorov luta pela autonomia do exército frente ao poder político, como Pudovkin frente as agências governamentais.

A trama perpassa a tensão entre o corpo militar profissional, que passa da glória pra o espezinhamento frente ao novo modelo composto por oficiais que se dedicam apenas às paradas militares e não ao treinamento bélico, que desconhecem ${ }^{53}$. Quando o regime se percebe em perigo, retira esse antigo corpo técnico do ostracismo, que é alçado às posições de mando, recebendo as honras na capital. E assim pode repetir as conquistas do passado. Ao escolher esse enredo centrado na oposição Suvorov-Paulo I, frente a muitos outros possíveis, como o da própria carreira vitoriosa do marechal russo, Pudovkin permite supor que abria uma janela para a situação da URSS naquele momento. O exército, esmagado pela repressão, precisa ser reconstituído e treinado. A tradição, posta fora, precisa ser reestabelecida. E, uma vez que a maior parte dos expurgados não foi morta, mas afastada, era previsível que fossem restabelecidos com a eclosão da guerra. O que de fato ocorreu.

Paulo I é representado segundo o mesmo quadro composto por Petrov - a de um aristocrata que se faz beijar os pés. Ao mesmo tempo possui uma postura operística, que lembra os personagens de Eisenstein. O que realça sua visão como um romântico, que prefere decorar a sala do trono com a bandeira da Ordem de Malta (antiga Ordem dos Cavaleiros Hospitalários), da qual era grão-mestre, à russa. A visão de um disciplinador, sonhador cavalheiresco e de reformador que mitigou a opressão a que os servos russos foram submetidos sob o governo de sua mãe, Catarina, II a Grande, é recente, de fins do século XX. A historiografia conservadora russa - e soviética - o mostra como um déspota que eliminou antigos foros e direitos políticos

\footnotetext{
53 Tal comportamento estava mais disseminado pelas Forças Armadas do que Pudovkin sugere ao confiná-lo ao programa irrealista de aristocráticos generais da corte e ao desvairado Paulo I. Em táticas, treinamento, artilharia, mosquetaria, organização e unidades (com exceção da cavalaria leve), o exército russo era inferior ao francês. Problemas estruturais difíceis de serem sanados. "Na falta disso, elementos de parada militar dominavam o treinamento, atingindo às vezes níveis absurdos de pedantismo e obsessão" (LIEVEN, 2014, p.41). Montefiore (2016, p.334-335) afirma que havia uma parada diária, a Watchparade, com antigos uniformes prussianos, que eram a principal ocupação para o czar.
} 
da nobreza da corte e das províncias, aumentando seu poder pessoal. Em alguns momentos Pudovkin permite identificar Paulo I como a imagem negativa de Stalin: prefere a fidelidade ao mérito, procede de maneira ideológica e não em fatos reais, cerca-se de aduladores, é um autocrata atormentado por qualquer sinal de oposição às suas ordens, cujo castigo é assimétrico ao delito. O czar ordenou a um regimento desobediente que marchasse até a Sibéria. Suvorov chama Catarina II, a Grande, de Mãezinha. Assim, um bom líder é sucedido por um ruim, Paulo, "o Louco" 54 . O que poderia suscitar, para muitos, a transição Lenin-Stalin. Se foram episódios reais do século XVIII, ao serem todos elencados, acabavam atingindo memórias recentes que poderiam ser relacionadas.

Se Suvorov dirige o trabalho coletivo de seus homens, que se consideram um só sob suas ordens, causa espanto a forma pela qual o diretor trata do fim da Campanha dos Alpes. O marechal ganha o prêmio pessoal do título de generalíssimo e uma estátua de bronze. Em seguida vira sua cabeça. Observa seus homens marchando nas escarpas nevadas. Esfarrapados, famintos, congelados. Todo o esforço desprendido de nada adiantou. Pior que isso, deixou seu exército numa situação desesperadora, cercado por Masséna. Os veteranos exclamam: "fomos levados para onde não há caminhos, não há saídas". O que Suvorov pede são mais sacrifícios atacar e cruzar a Ponte do Diabo, estreita, longa, sobre o precipício do rio Reuss, facilmente defensável, mas na retaguarda francesa. A vitória abriria caminho para o paraíso com "pão e sol até fartar-se". Abrir caminho corajosamente para a retirada.

Na realidade, só recebeu o título de generalíssimo após a campanha, em outubro de 1799, quando Paulo I decide encomendar sua estátua, ainda em vida ${ }^{55}$. O teste de fogo não foi a Ponte do Diabo, mas a descida pelas encostas do Passo Paniks, no vale do Reno. A crítica ao programa de modernização da URSS baseado na industrialização acelerada e na coletivização agrária já havia sido realizada de forma sutil por Alexandrov em sua comédia musical VolgaVolga, de 1938, em que aponta para uma industrialização inócua. As incongruências históricas em Suvorov apontam para uma direção: a liderança criou sua imagem tendo por base o caminho tomado, mas este estava errado. Trabalho árduo seria necessário para a superação das novas

\footnotetext{
${ }^{54}$ Parece equivocada a interpretação de Dobrenko (2008, p.92) de que Suvorov capitaneia o povo contra o czarismo. Não há uma oposição ao poder centralizado, mas sim a forma como é dirigido.

${ }_{55}$ Recebeu ainda o título "romântico", uma vez que não estava lastreado pelo poder de fato, de príncipe da Itália, após sua vitória em Novi, nas proximidades de Gênova, em 1799 - o que gerou ciúmes em Paulo logo em seguida (MONTEFIORE, 2016, p.344), o que poderia ser entendido como mais uma alusão à Stalin e sua tumultuosa relação com subordinados (expressa memoravelmente em sua posterior crise com o marechal Zhukov).
} 
dificuldades. Se o Pacto de Não-agressão parecia inicialmente uma jogada exitosa, os contemporâneos perceberam gradualmente o contrário, como demonstram os irmãos Medvedev (2006). Na URSS esperava-se que as democracias liberais europeias e os nazi-fascismos se digladiassem até a completa exaustão, repetindo o cenário da Primeira Guerra Mundial e invertendo o que o Kremlin acreditava ser o plano anglo-francês de abandono da União Soviética ao Eixo. Porém a Europa cedeu como um castelo de cartas, em especial em maiojunho do mesmo ano de 1940, quando a França sucumbiu em um mês e meio. A Alemanha não se desgastou na luta. Pelo contrário, agora contava com tropas voluntárias de direitistas de todos os países ocupados ${ }^{56}$ ou arregimentadas pelos regimes satélites, com o parque industrial e bélico francês e todo o armamento intacto deixado pelos países derrotados, em especial pelos ingleses em Dunquerque.

Figura 3. O velho e o nove se cruzam no filme de Pudovkin

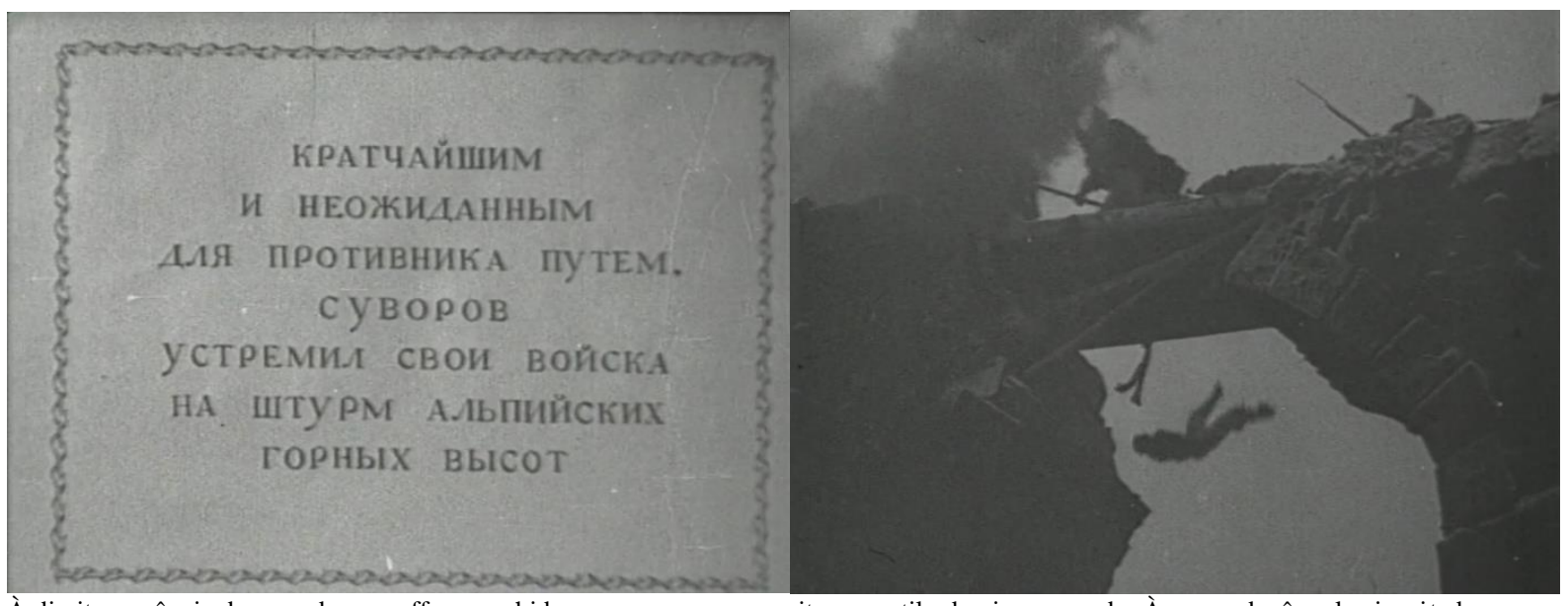

À direita, ausência do narrador em off, preenchido com mensagens escritas no estilo do cinema mudo. À esquerda, ângulos inusitados, como a escola inovadora soviética tão bem soube oferecer. Fonte: SUVOROV, 1940.

Ao mesmo tempo, o próprio Suvorov poderia ser comparado com a visão oficial de Stalin. Disciplinador sem pompas, líder motivacional, mente capaz de organizar e conduzir grandes conquistas coletivas, instruído, direto, inflexível diante de desafios e cercado por inimigos internos e externos. Ao perceber a traição de subordinados e de austríacos ${ }^{57}$, conduz o fuzilamento sem tribunal. Stalin citava alguns pensamentos deixados por Suvorov em seu

\footnotetext{
${ }^{56}$ Bons exemplos são as divisões Waffen SS Wallonien, de belgas; Charlemagne, de franceses; Nordland e Viking, de escandinavos; Handschar, de croatas.

${ }^{57}$ Montefiore (2016, p.344-346) também fala em traição quando os austríacos retiraram suas forças e deixaram Suvorov sozinho nos Alpes, o que teria feito Paulo abandonar a expedição, chamando-o de volta, e até cogitado a se unir aos franceses contra os aliados Habsburgos e britânicos (culpando estes pelo desastre na Holanda).
} 
livro A ciência da vitória, que acabaram sendo repetidos no filme: "a velocidade é a companheira da vitória", "um verdadeiro líder vence o inimigo antes de chegar até ele. Venceo primeiro com as ideias, depois com a ação". Tenta em vão alertar o meio militar para a crescente ameaça napoleônica, como a diplomacia soviética não recebeu apoio em sua frente anti-fascista com Inglaterra e França antes da assinatura do Pacto Ribbentrop-Molotov. Paulo ou Suvorov? Stalin estaria realmente ali? O hábil uso da ambiguidade pelo diretor permite múltiplas leituras. E o protege eficazmente da censura, ao menos até 1946. Pudovkin e Doller sabiam muito bem do perigo que corriam caso não explorassem espaços de atuação com eficiência. Doller foi acusado pela OGPU ${ }^{58}$ em 1929 de ser um inimigo de classe. Pudovkin acabou arrolado no mesmo processo. Ao trocar sua equipe de trabalho, acabaram se livrando do processo. ${ }^{59}$ Outros diretores não tiveram a mesma sorte, como Margarita Barskaia (190339), que morreu no Gulag, ou Boris Shpis (1903-39), que foi fuzilado. ${ }^{60}$

Figura 4. O uso de closes fechados sobre o rosto dos atores, inclusive da reação daqueles que apenas ouvem os diálogos

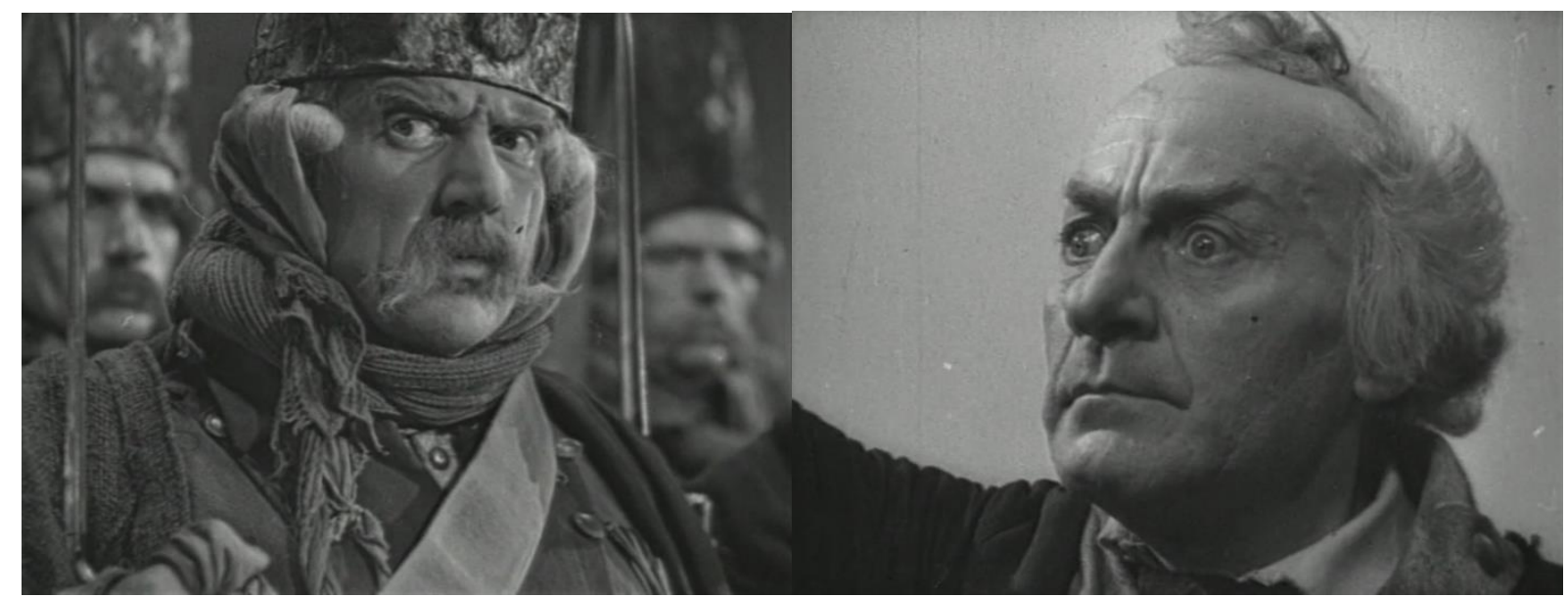

Fonte: SUVOROV, 1940.

\footnotetext{
${ }^{58}$ Antecessora do NKVD, que precedeu o KGB.

${ }^{59}$ MILLER, 2010, p.75.

${ }^{60}$ KENEZ, 1992, p. 153.
} 
Figura 5. Suvorov persigna a Bagration antes da conquista de São Gotardo (24 de setembro de 1799). Sua tropa escala os Alpes acima das nuvens

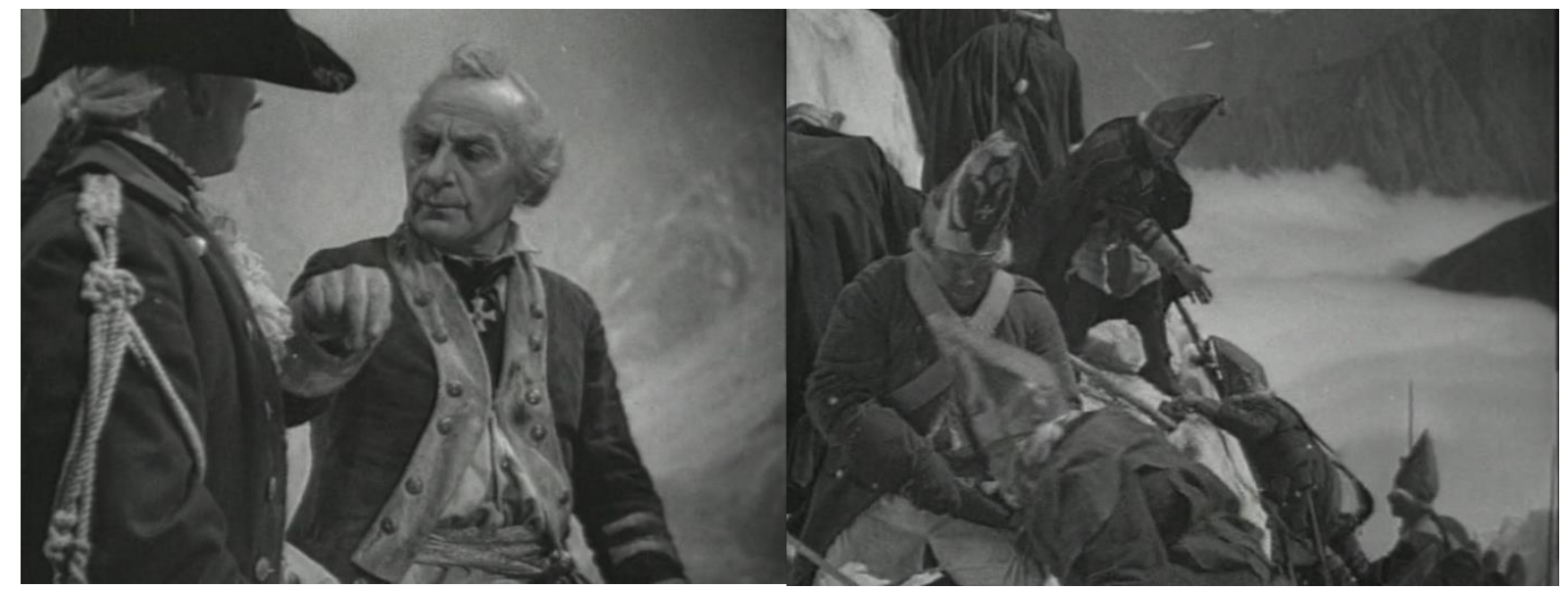

Fonte: SUVOROV, 1940.

A obra de Pudovkin estava muito distante do que Furhammar e Isaksson (2003, p.148) consideram um filme de propaganda. O herói, por mais que seja impetuoso e emotivo, tem como apoio fundamental o planejamento da ação. É um dissidente de seu governo. Vai muito além de cenas de ação ou violência. Não apela apenas para o sentimento do público, já que "a propaganda se dirige às emoções e não ao intelecto".

Uma característica importante da cartilha do realismo socialista era o apelo pelo didatismo e correção histórica - ou, na prática, a história oficial do momento - e a capacidade de entretenimento, ${ }^{61}$ para que a plateia simplesmente votasse com os pés e abandonasse a exibição, como ocorria com os filmes de Eisenstein. Suvorov consegue atingir os dois objetivos. É didático não apenas quando trata das peripécias do marechal russo, como os versos que escrevia satirizando um paranoico Paulo I, mas também como o material de campanha pública que o governo necessitava. Stalin não baixava decretos aleatoriamente, exibindo o perfil de ditador totalitário. Isso atingiria sua popularidade, que se baixa entre russos do norte do Cáucaso ou na maior parte da Ucrânia, era elevada em outras regiões. Um poder político baseado apenas na força repressora não pode se perpetuar. Antes de cada investida o Kremlin procurava montar uma estratégia de propaganda nos meios de comunicação e círculos comunistas, assim obtendo apoio ou compreensão popular antes de implementar ações. Vinte anos antes, muitos soviéticos lutaram numa guerra civil na qual aprenderam a importância da presença de oficiais políticos

${ }^{61}$ LAWTON, 1992, p.84. 
no comando militar, bem como da instrução política-ideológica. Suvorov mostrava que um exército precisava ser antes de tudo profissional, legitimando as propostas de reestruturação das forças armadas.

Paulo I teria viciado a instituição ao torná-la uma decoração palaciana. O filme, no entanto, não vai além disso. Exibe as tropas marchando para um lacrimejante Paulo, no palácio Gatchina, com o passo de ganso, que parte dos expectadores poderia relacionar com a cópia de elementos prussianos. Mas não o faz abertamente. Paulo louva seu exército feito máquina. Suvorov insurgisse por um exército patriarcal, no qual pode chamar seus soldados de filhos e ser chamado de pai ${ }^{62}$. Pudovkin, no entanto, jamais cria um diálogo ou legenda que aponte que a reforma do czar objetivava importar técnicas e ordenanças prussianas, rejeitando as tradições russas declamadas pelo marechal. Um motivo para a ausência é que a própria reforma de 1940 procurava aproximar o Exército Vermelho de seus congêneres estrangeiros. O que poderia avizinhar perigosamente a imagem de Paulo à de Stalin.

Inicialmente Pudovkin não queria realizar filmes históricos. Preferia temas contemporâneos. Acabou realizando dois filmes de época quase simultaneamente: Minin $e$ Pozharski (1939) e o próprio Suvorov. Após a guerra, seria a vez de Almirante Nakhimov. Essa mudança pode ser explicada pela percepção do potencial de crítica sutil dos tempos atuais que o cinema histórico proporciona.

Suvorov é uma obra de transição. Sonoro, mas com recursos do cinema mudo: a recriação de quadros históricos, como Suvorov nos Alpes, e a ausência do narrador em off, substituído pelo uso de telas com o texto escrito, o que já entrava em desuso na época, mas não na URSS, onde muitas salas de exibição continuavam a carecer do equipamento de som. A deficiência destas salas, concentradas no interior do país, obrigava os estúdios de cinema a produzirem duas versões do mesmo filme: sonoro e mudo. Neste último caso, acrescentando legendas e telas com letreiros de acordo com a necessidade. Conta com a plasticidade do cinema em preto e branco, com os closes nos rostos dos demais atores da cena durante uma fala.

\footnotetext{
${ }^{62}$ Dobrenko acredita que essa relação se contrapõe ao modelo externo prussiano, que, ao não ser paternalista como de Suvorov, saturado de comportamentos eslavos, não conseguiria manter a mesma unidade da tropa, atravessada pela falta de humanidade dos especialistas prussianos. Um aviso aos cosmopolitas adeptos de estrangeirismos. Suvorov seria visto como o pai de um exército popular. Ao focar as campanhas no Ocidente, e não na Rússia, o filme não seria patriótico, mas sim personalista, ao defender esta para a unidade do exército. "Ele é astuto como Stalin" - o que indica a qual personalidade se inclina. O czar e seu regime/corte seriam antipatrióticos, enquanto o povo, incorporado no exército, seria de fato patriótico. O povo é superior ao czar, e com isso, o regime soviético ao czarismo (DOBRENKO, 2008, p.90-91).
} 
Pudovkin abandonou suas teses sobre o som e cedeu ao academicismo dominante. ${ }^{63}$ A trilha sonora de Suvorov foi composta por Yuri Shaporin, e é formada por canções militares de época.

Figura 6. O líder olha por seu povo. Suvorov (1940), de Pudovkin, e Ivã, o Terrível (1944), de

\section{Eisenstein}



A imagem mostra uma possível influência de Pudovkin sobre Eisenstein, bem como as maneiras diferentes dos diretores de lidar com a montagem da cena e o uso dos planos da imagem para a criação de trucagens, de efeitos visuais e dramáticos. Pudovkin fez bom uso de suas teorias de montagem (XAVIER, 1983, p.69-70) em Suvorov, criando, como Kuleshov, uma "geografia criativa". Ao invés de filmar nos Alpes Réticos, Glaroneses e Lepontinos, estabeleceu seus sets nas altas montanhas da Ásia Central soviética. Fonte: SUVOROV, $1940 ;$ IVÃ, 1944.

Pudovkin certamente utilizou material iconográfico produzido nas décadas anteriores para montar seus cenários, figurino e ambientação. Pintores russos do período czarista imortalizaram as façanhas do marechal em diversas ocasiões: sua vitória no Passo de São Gotardo, no Norte da Itália, sobre turcos e poloneses, etc. Geller pincelou Suvorov em sua casa rústica no exílio, e em seu estilo pessoal ainda mais simples. Maltratado pelos ferimentos de guerra, em um pé usava bota militar. No outro, sapato. Existem descrições escritas sobre a sua aparência em sua intimidade. Porém, todos os pontos coincidem com aqueles utilizados por Geller, entre tantos outros possíveis. A única diferença é a inversão do pé mutilado. Reproduções quase perfeitas de várias obras aparecem frequentemente na película. Poderiam ser reconhecidas por parte da plateia. É o caso de quadros de representações de batalhas, como os de Vasili Surikov - que pincela o ludíbrio que impôs Suvorov à Napoleão em sua fuga alpina como uma diversão na neve comandada pelo generalíssimo do czar, com a alegria estampada

${ }^{63}$ LABARRÉRE, 2009, p.339. 
no rosto - e Alexander Kotzebue - que imprime o drama do combate na passagem entre as montanhas com o uso das vertigens provocadas pelos desfiladeiros dos Alpes, mesclando a névoa da paisagem natural, vinda da garganta, com aquela provocada pelos disparos e fuzilaria de carabinas, mosquetes e artilharia. Impressionante linguagem visual adaptada às telas.

Foi um grande sucesso nas telas das salas de cinema através do país. ${ }^{64} \mathrm{O}$ regime apreciou o resultado do filme. Em 13 de março de 1941 concedeu ao diretor Pudovkin e ao co-diretor Doller, bem como ao ator Nikolai Cherkasov-Sergeev, o prêmio de primeiro grau no Prêmio Stalin em Literatura e Arte, equivalente a 100 mil rublos. Miller (2010) consideraria esse procedimento como uma estratégia de cooptação por parte do Estado, que alternava castigo e recompensa para controlar a arte. Esse modelo é composto a partir da ótica política das necessidades do Kremlin. No entanto, não ocorreu uma adesão forçada ou baseada na aquisição de vantagens, já que ela não se ocorreu de todo. Na prática, o que o governo soviético conseguiu foi criar um regulamento que impunha seus termos ao definir os limites da arena artística, sem substituí-la. Ela continuou a existir, com suas tensões e choques de interesses. Stalin teve uma opinião própria sobre o filme, ao dizer para Pudovkin, em 1940: "você fez um bom filme sobre Alexander Vasilievich Suvorov, agora precisa fazer um filme sobre o comandante Suvorov". ${ }^{65}$

\footnotetext{
${ }^{64}$ Segundo Rollberg, "Quando, no final dos anos 1930, o establishment soviético se afastou do internacionalismo proletário e integrou o nacionalismo russo como um pilar em seu arsenal ideológico oficial, a história russa teve de ser interpretada de um ponto de vista patriótico. Como Eizenshtein, e de acordo com as diretrizes oficiais do Partido, Pudovkin foi encorajado a tentar a sorte em assuntos his tóricos com foco em grandes personalidades. Abandonando a experimentação formal quase completamente, Pudovkin comandou Minin e Pozharskii (Minin i Pozharskii, 1939) e Suvorov (também conhecido como General Suvorov, 1941), ilustrando a luta russa contra invasores poloneses no século 17 e os primeiros estágios da guerra contra Napoleão, respectivamente. De acordo com o historiador do cinema Oksana Bulgakowa, o último filme foi inspirado pela doutrina pré-1941 de Iosif Stalin de que a guerra que se aproximava seria travada em território estrangeiro - o que fez de Suvorov, cujas vitórias celebradas ocorreram na Itália e na Suíça, o herói do dia. Ambas as fotos foram populares com o público e deram ao diretor seu primeiro Prêmio Stalin em 1941. Suvorov também é notável por seu papel principal, Nikolai Cherkasov-Sergeev (1884-1944), que encarna o lendário estrategista como um líder extravagante quase Chapaeviano, pai de seus soldados e sem medo de czares ou cortesãos" (ROLLBERG, Peter. Historical dictionary of Russian and Soviet cinema. Lanham: Scarecrow Press, 2009, p.554). A tese de que um ataque à URSS deveria ser rapidamente bloqueado e, com um potente contra-ataque, a guerra deveria ser travada em território inimigo, poupando o país dos males dos confrontos, surgiu com o caído Tukhachevsky, inimigo pessoal de Stalin após a derrota diante de Varsóvia em 1920, e permaneceu como norte para a estratégia soviética mesmo após a execução do marechal, em 1937, e a sua posição fantasiosa deve ser creditada como parte do desastre de 1941. A escolha das campanhas de Suvorov para a película reforçavam a doutrina militar vigente, além de acalmar a população sobre a ameaça de mais uma invasão.

${ }^{65}$ DOBRENKO, 2008, p.89.
} 
Figura 7. A pintura serve de modelagem para a representação fílmica da história

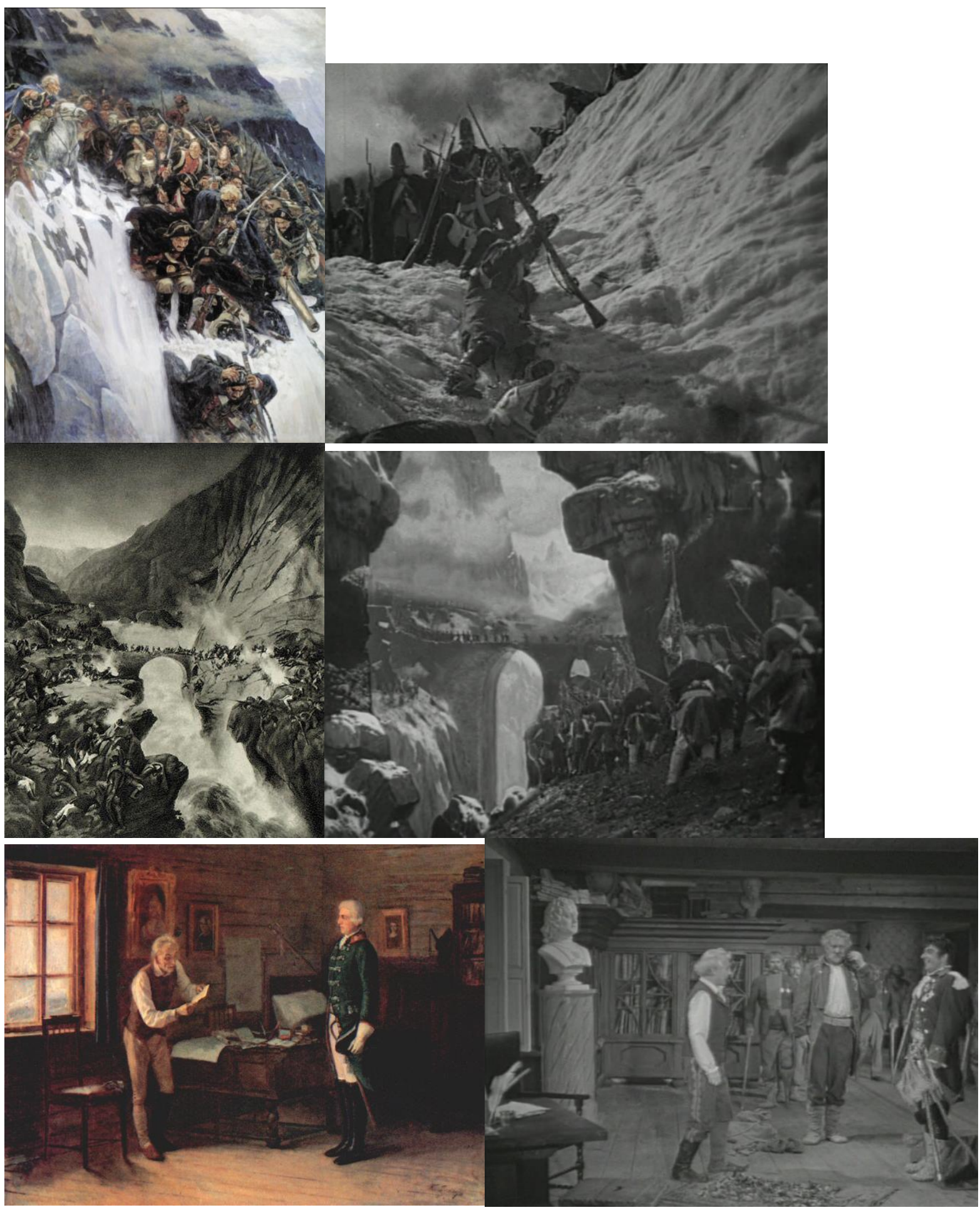

Acima: Suvorov cruza os Alpes, de Vasili Surikov (1848-1916). No meio, Ponte do Diabo, de Alexander Kotzebue (1815-1889). Abaixo, Suvorov no exílio, de Peter Geller (1862-1933). Fonte: SUVOROV, 1940. 
Figura 8. Paulo I e Suvorov

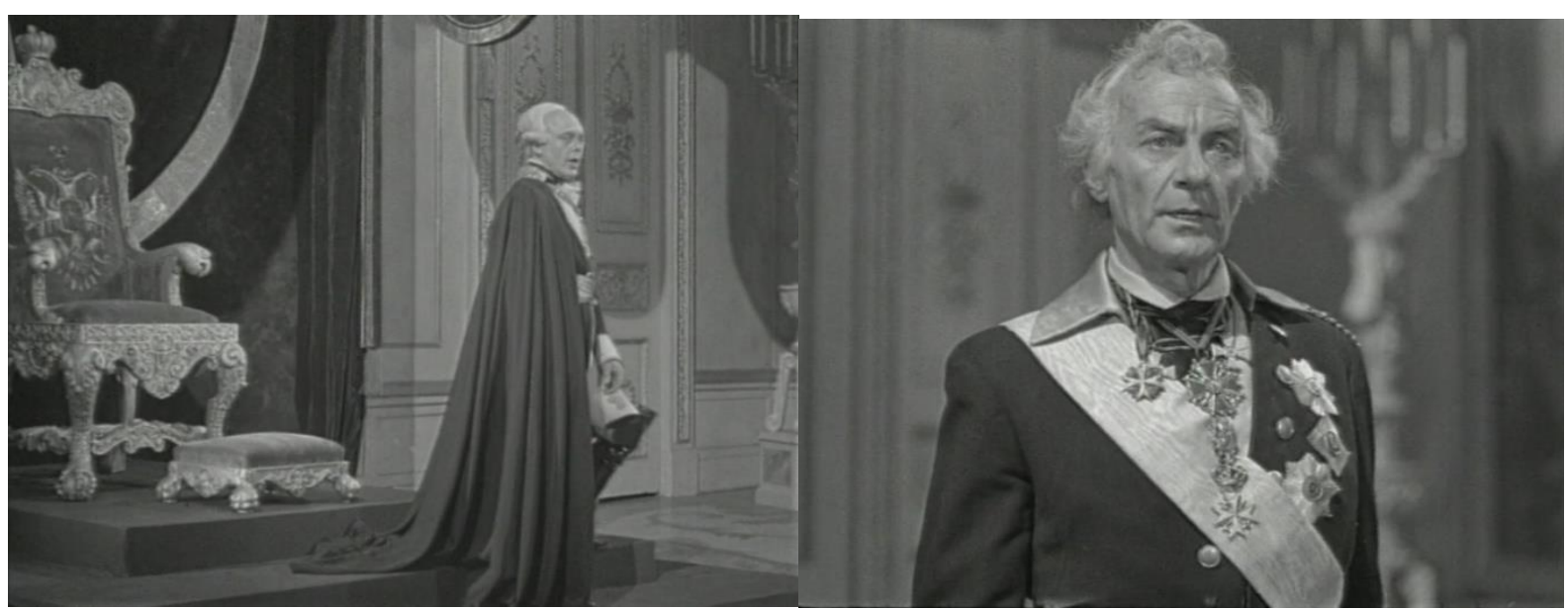

A montagem de contraste, como aponta o próprio Pudovkin (XAVIER, 1983, p.63-64), forçar o espectador "a comparar as duas ações durante o tempo todo, sendo que uma reforça a outra”. O diretor contrapõe planos com o pomposo, ajanotado e grave czar Paulo I, com a capa de GrãoMestre dos Cavaleiro de Malta e a bandeira da ordem atrás do trono, com o desgrenhado, cético e irreverente Su vorov. Fonte: SUVOROV, 1940 .

\section{CONCLUSÃO}

O retorno às tradições militares czaristas sob Stalin deve ser entendido não como um episódio motivado pela Segunda Guerra Mundial, uma vez que esta restabeleceu temporariamente o poder dos comissários políticos. Mas sim como uma etapa do processo maior do avanço conservador sobre a sociedade e a política soviéticas e do arrefecimento do ímpeto revolucionário. É a outra face do retorno à autocracia que abateu os poderes oligárquicos locais herdados do leninismo, da revanche do nacionalismo sobre o internacionalismo, do regresso da religiosidade e de concepções habituais da ordem social. Essas transformações se deram com algum desconforto, pelo contraste entre expectativas e realidades, objetivos e meios, impulso por mudança e inércia estrutural. Como também pelos posicionamentos dos diferentes setores da sociedade da União Soviética, que percebiam esse movimento como sendo de um retrocesso brumarista, ou que a revolução havia de fato se tornado radical demais e precisava se normalizar, ou ainda que apreciavam a antiga Rússia czarista.

O cinema tomou parte deste processo, cindido entre dois pontos de tensão: a expectativa do regime em comissionar as películas por meio do sistema de estúdios estatais e usá-las como campanha publicitária de sua nova diretriz militar, e a busca por parte de seus produtores de usufruir da liberdade criativa, que caracteriza a arte como tal. 
Pudovkin, teórico do uso da ambiguidade na narrativa fílmica, conseguiu sugerir críticas sutis ao regime sem comprometer sua obra ou sua pessoa. $\mathrm{O}$ diretor inseriu chaves de leitura múltiplas no filme. O stalinista convicto poderia ver em Suvorov uma ode aos ideais socialistas, à administração de Stalin, uma justificativa baseada na profissionalização para a eliminação de comissários políticos e da mudança do currículo das escolas militares, e um alerta ao perigo externo em que a URSS se encontrava, por se opor a inimigos poderosos e contar com aliados nada confiáveis. O stalinista de ocasião, ou a oposição silenciosa, poderia conceber uma leitura totalmente diferente, principalmente pelo uso de sua memória recente: se o exército urge reformas deve-se a sua desorganização pela purga stalinista, a intromissão do poder político em assuntos técnicos-militares só poderia resultar em problemas numa hora tão crucial quanto 1940, execuções sem julgamento, um apelo pela autonomia. Pudovkin era um artista revolucionário engajado. Enfrentou dissabores com a repressão policial e a censura e morosidade do Ministério do Cinema. Produziu um filme tão aberto que, dentro do espectro anti-stalinista, um trotskista ou mesmo um ex-combatente ou simpatizante branco poderia encontrar algum elemento para embasar suas suposições. Uma mesma plateia, diferentes mensagens e uma gama ainda maior de interpretações possíveis.

\section{REFERÊNCIAS}

Fontes

PUDOVKIN, Vsevolod. Suvorov (108 minutos). Mosfilm: 1940.

\section{Obras Gerais}

BAZIN, André. O mito de Stálin no Cinema Soviético. In: BAZIN, André. O que é o Cinema? São Paulo: Cosac Naify, 2014.

BRANDENBERGER, D. National Bolshevism: Stalinist mass culture and the formation of modern Russian national identity, 1931-1956. Cambridge: Harvard University Press, 2002.

BROWN, A. The Rise and Fall of Communism. Londres: HarperCollins, 2010.

BURKE, P. Testemunha ocular: história e imagem. Bauru: EDUSC, 2004. 
CAPELATO, M. H. et al. História e cinema. São Paulo: Alameda, 2011.

CHARTIER, R. A história hoje: Dúvidas, desafios, propostas. Estudos Históricos, vol. 13, n.7, p.97-113. Rio de Janeiro, 1994.

CHARTIER, R. Do livro à leitura. In: CHARTIER, R. (Org.). Práticas da leitura. Brasília: Estação Liberdade, 1996.

DARNTON, R. Cinema: Danton e o duplo sentido. In: O beijo de Lamourette: mídia, cultura e revolução. São Paulo: Companhia das Letras, 1990.

. O diabo na água benta. São Paulo: Companhia das Letras, 2012.

DOBRENKO, E. Stalinist cinema and the production of history. Edinburgo: EUP, 2008.

FERRO, M. Cinema e História. São Paulo: Paz e Terra, 1992.

. O filme: uma contra-análise da sociedade? In: LE GOFF, J.; NORA, P(Org.). História: novos objetos. Rio de Janeiro: Francisco Alves, 1976.

FURMHAMMAR, L.; ISAKSSON, F. Cinema e política. Rio de Janeiro: Paz e Terra, 2003.

GIBELLI, N. A Segunda Guerra Mundial. Vol. 3. Rio de Janeiro: Codex, 1966.

KAMINSKI, R. Da narração literária às telas do cinema: camadas de sentido alegórico em A Guerra dos Pelados. História Questões \& Debates, v. 44, p.87-114. Curitiba, 2006.

KENEZ, P. Cinema and Soviet society, 1917-1953. Cambridge: Cambridge Press, 1992.

LABARRÉRE, A. Z. Atlas del cine. Madrid: AKAL, 2009.

LAWTON, A. (Org.). The Red screen. Londres: Routledge, 1992.

LEWIN, M. O fenômeno Gorbachev. Rio de Janeiro: Paz e Terra, 1988. O século soviético. Rio de Janeiro: Record, 2007.

LEYDA, J. Kino: a history of the Russian and Soviet film. Princeton: Princeton University Press, 1983.

LIEVEN, Dominic. Rússia contra Napoleão: a batalha pela Europa de 1807 a 1814. Barueri: Amarilys, 2014.

MARCOU, L. A vida privada de Stálin. Rio de Janeiro: Zahar, 2013.

MARSHALL, H. Masters of the Soviet Cinema. Abingdon: Routledge, 2013.

MEDVEDEV, Z.; MEDVEDEV, R. Um Stalin desconhecido. Rio de Janeiro: Record, 2006. 
MILLER, J. Soviet cinema. Londres: IB. Tauris, 2010.

MONTEFIORE, Simon Sebag. Os Románov: 1613-1918. São Paulo: Companhia das Letras, 2016.

MORETTIN, E. V. O cinema como fonte histórica na obra de Marc Ferro. História: Questões \& Debates, v. 20, n.38, p. 11-42. Curitiba, 2003.

NAVARRETE, E. O cinema como fonte histórica: diferentes perspectivas teóricometodológicas. Revista Urutágua, n.16, p. 1-7. Maringá, 2008.

OLIVEIRA, D. O cinema como fonte para a história. Fontes históricas: métodos e tipologias, 2008, Curitiba. III Evento de Extensão em Pesquisa Histórica, 2008.

PERRIE, M.; LIEVEN, D.; SUNY, R. G. (Org). The Cambridge History of Russia. Cambridge: Cambridge University Press, 2006.

POSPELOV, P. La Gran Guerra Patria de la URSS. Progreso: Moscou, 1975.

RADOVIC, Stanka. On the threshold: Terrain vague as living space in Andrei Tarkovsky's Stalker. In: BARRON, P.; MARIANI, M (Org.). Terrain Vague. Nova York: Routledge, 2014.

ROLLBERG, Peter. Historical dictionary of Russian and Soviet cinema. Lanham: Scarecrow Press, 2009.

ROSENSTONE, R. History on Film/Film on History. Harlow: Pearson, 2006.

SORLIN, P. La storia nei film. Firenze: La Nuova Itália, 1984.

TAYLOR, R.; SPRING, D. Stalinism and Soviet cinema. Nova York: Routledge, 1993.

THOMPSON, E. P. Costumes em Comum. São Paulo: Cia. das Letras, 1998.

VALIM, A. B. Imagens vigiadas: uma História Social do Cinema no alvorecer da Guerra Fria - 1945-1954. 324 f. Tese (Doutorado em História), Universidade Federal Fluminense, Niterói, 2006.

VOLKOGONOV, Dmitri. Stalin: triunfo e tragédia. Rio de Janeiro: Nova Fronteira, 2004.

WERTH, Alexander. A Rússia na Guerra. Rio de Janeiro: Civilização Brasileira, 1966.

XAVIER, I. (Org.). A Experiência do cinema. Rio de Janeiro: Graal/Embrafilme, 1983. 